\title{
Containment and Support in Baltic Languages: Overview, Experimental Evidence, and an Extended RCC as Applied to Latvian and Lithuanian
}

\author{
Eglè ŽILINSKAITĖ-ŠINKŪNIENE ${ }^{1}$, Jurğis ŠĶILTERS ${ }^{2,1}$, \\ Līga ZARIN̦A ${ }^{2}$ \\ ${ }^{1}$ Vilnius University, Institute for the Languages and Cultures of the Baltic, Faculty of Philology, \\ Universiteto st. 5, Vilnius, Lithuania \\ ${ }^{2}$ University of Latvia, Laboratory for Perceptual and Cognitive Systems at the Faculty of \\ Computing, Faculty of Computing, Raina blvd. 19, Rīga, Latvia
}

egle.zilinskaitedflf.vu.lt,jurgis.skilters@lu.lv,liga.zarina@lu.lv

\begin{abstract}
The paper deals with the spatial relations of containment and support in the Baltic languages in a geometric framework. The geometric framework in our research is based on Region Connection Calculus representing different combinations of two circles depending on primitive topological relation of connectedness and extended with the distance, size, orientation and partial occlusion primitives. The research summarises results of two experiments conducted with 105 Latvian and 106 Lithuanian native speakers, provides the interpretation of 8 support and 5 containment stimuli, and gives a preliminary overview of correlation between different independent variables and the granularity and length of the spatial descriptions. Our results indicate a great variation in interpreting the given stimuli in each language, but the contrastive empirical analysis reveals that heterogeneity of interpretation in both languages is similar. For perception of support and containment relations, axial information and connectedness are the determining primitives.
\end{abstract}

Keywords: containment, support, RCC, geometry, the Baltic languages.

\section{Introduction and theoretical framework}

Spatial descriptions in natural languages usually encode relations between objects. The object which is being located in the spatial scene is called the Figure while the reference object in relation to which the Figure is located is called the Ground (Talmy, 1972; 2000). Thus, such spatial utterances that indicate the location of the Figure in relation to the Ground are referred to as relational spatial constructions (Svorou, 2007, 726; Sinha and Kuteva, 1994).

Spatial relational constructions may be locational or directional. The former are represented by static situations while the latter are defined as movement from one place to another (Miller and Johnson-Laird, 1976; Wunderlich, 1991; Wunderlich and Herweg, 1991; Asbury et al., 2008; Zwarts, 2017). The motion of the Figure takes place along a certain path. The maximal windowing of the path event frame encompasses three elements: the beginning of the path (or Source), trajectory (or Medium) and the end of 
the path (or Goal) (Talmy, 2000a, 265). Linguistically, maximal windowing is rarely explicit. Research based on both corpus (e.g. Stefanowitsch and Rohde, 2004) and experimentally retrieved data (e.g. Lakusta and Landau, 2005) clearly show linguistic asymmetry between Source and Goal of motion: source information is often omitted, but the Goal of motion is expressed.

Static spatial relations may involve angular information: such spatial scenes require certain frames of reference (intrinsic, relative or absolute, Levinson, 2003). When none of the three frames of reference is employed, static relations are topological or geometric indicating that the Figure and the Ground are contiguous or in close vicinity with each other (Levinson and Wilkins, 2006).

The model for description of the so-called topological or geometrical spatial relations has been subject to debate. Early studies focused on descriptive, structural and logical analysis (Lindquist, 1950; Cooper, 1968; Bennett, 1975, among others) representing traditional core-meaning approach and mostly based on the topological or geometric properties. Geometric properties of the Figure, the Ground and the relation between them were most important also for Herskovits when providing the ideal meaning of English topological prepositions in, on and at defined as the geometric idea of the preposition (Herskovits, 1986, 18). But Herskovits also proposed the extensions from the ideal meaning as this ideal meaning is manifested in the rest of the meanings (or use-types) via the pragmatic near-principles of salience, relevance, tolerance and typicality (idem, $18,73 \mathrm{ff})$.

Research on categorization in cognitive psychology and emergence of cognitive linguistics led to numerous linguistic studies focusing on the polysemy of spatial prepositions as radial categories displaying prototype effects and instantiated by different variations of radial or lexical networks. The seminal papers focused on preposition over and verb particles out and up (resp. Brugman, 1981, and Lindner, 1981) and led to a variety transformations criticized for methodological inconsistency and the maximalist approach (Sandra and Rice, 1995; Rice, 1996, among others). Several papers proposed more elaborated framework, also for topological prepositions, focusing more on context and object conceptualization and categorization (e.g. Hottenroth, 1991) or interaction of geometric, functional and force-dynamic properties (Hawkins, 1984; Vandeloise, 1991; 1994; Navarro, 1998, among others). Functionally-oriented experimental approach showed the importance of functional knowledge and typical patterns of interaction between objects (Coventry et al., 1994; Carlson-Radvansky et al., 1999; Garrod et al., 1999; Feist, 2000; Feist and Gentner, 2003; 2012; Coventry and Garrod, 2004; Gärdenfors, 2014). The importance of functional factors was emphasized also by research into abstract domains of topological/geometrical prepositions, namely English in and on, showing that the choice of the preposition depends on the extent of control of the Figure or the Ground in Figure-Ground relationships: the Figure has less control in the Ground than on it and vice versa for the Ground (Jamrozik and Gentner, 2015).

More recent studies put emphasis on the labour between geometric and functional factors (Landau, 2017; Zwarts, 2017). According to Landau (2017), different prepositions show a different impact of geometry and function. For instance, so-called English geometrical prepositions in and on are actually force-dynamic as they are primarily based on force-dynamic relations between the objects in the spatial scene. Despite the fact that cross-linguistically and developmentally these terms appear very early (Johnston and Slobin, 1979), their acquisition is lifelong as it depends on the introduction of the new contexts containing these prepositions. On the contrary, above/below and right/left, are based on geometric features, such as distance and 
direction, and even they are acquired later that in and on, human knowledge about their usage needs not to be supplemented throughout the course of life. Finally, Zwarts (2017) does not observe a "fundamental conflict" between the studies of spatial cognition based on geometric vs. functional features.

Studies in semantic typology deal with different issues, i.e. the diversity of spatial cognition and language. Methodologically, the data is obtained by answering wherequestions and thus comparing basic locative constructions (Levinson and Wilkins, 2006; Feist, 2008; Gentner and Bowerman, 2009; Landau et al., 2017). And even though the question of geometry and function is not foregrounded, the focus on functional features is advocated in elicitation tools, namely, stimuli sets, that consist of various spatial scenes depicting different spatial relations of familiar objects as Figures and Grounds (e.g. 71 drawing in Topological relation picture series by Bowerman and Pederson (1992)). The results demonstrate high linguistic diversity but at the same time they reveal common or even universal tendencies how this diversity is structured, which means that the semantic space of topological notions is more or less coherent (Levinson et al., 2003, 498ff.) and can provide certain hierarchies for the topological relation markers. This account is supported by cross-linguistic research by Bowerman and Pederson (reviewed in Levinson et al., 2003, 499, 502; Bowerman and Choi, 2003, 484487).

An important issue of contrastive and cross-linguistic research is the diversity of spatial scenes and variables tested. The 71 picture in Topological relation picture series (Bowerman and Pederson, 1992) contrasts according to 22 criteria that partially overlap (e.g. Levinson and Wilkins, 2006, 9-10). Gentner and Bowerman (2009) focus on the different containment and support scenes (32 stimuli) that form a continuum ranging from prototypical support-from-below on the one hand to prototypical full containment on the other. They contrast English with Dutch and the latter language exhibits "the most exotic pattern for the handling of ON relations" (p. 470) as it carves the semantic space of contact and support with three different prepositions, namely, op, aan and om. This fact has consequences for learning to express the containment and support category for Dutch children: the acquisition of these spatial terms in Dutch takes place later than in English which covers the scenes of contact and support with the single preposition on Such results lead to a more general typological prevalence hypothesis: the more frequent the certain model of categorization is attested cross-linguistically, the easier it is for children to learn (idem, 467). Landau et al. use a recently developed battery of 44 stimuli for the categories of containment and support and explore them as complex categories that consist of various subtypes, e.g. loose fit and tight-fit full containment, loose fit and tight-fit partial containment, interlocking and embeddedness for containment category and gravitational support, embedded support, support via adhesion, support via hanging and support via point-attachment for support category. Certain subtypes instantiate the core of the category expressed by basic locative constructions while the other tend to be rendered with another linguistic means (Landau et al., 2016) and thus are acquired later by children (Johannes et al., 2016).

Our approach is based on a number of assumptions. First, we start the research of Baltic spatial language from containment and support relations as they constitute an essential part of human spatial reasoning. Containment is typically described as one of the most crucial and earliest conceptual primitives in the system of spatial cognition (Mandler, 2004; 2010). Eventually containment is generated by using bodily experience. According to Mandler (1992), when breathing or moving from one room to another, humans generate bodily schema of containment. Therefore, containment seems to be 
a developmentally early primitive (cp. also Hespos and Spelke, 2007). Support is another functionally significant spatial relation operating in virtue of gravity. Although several possible interpretations of support in real life situations are possible they all operate in virtue of gravity (cp. Landau et al., 2017). In our approach, we also assume that containment might be in most situations derived from other operators such as convexity or functional operators of locational control and support. In case of support, in contrast, we assume that support is a basic and non-derived operator.

Second, containment and support are usually considered core functional relations in spatial language. Therefore, most of the work done on containment and support uses functional stimuli (e.g. Landau et al., 2016; Coventry et al., 1994). In our approach, we assume that neither geometric nor functional features are reducible or eliminable and play a complementary role in interpretation of spatial relations. At the same time, we also agree that object information (e.g. shape, size, functions, material) and the purpose of use can substantially contribute to the interpretation of the spatial relations. In this work, we explore geometric relations in respect to containment and support. In geometric framework, the containment and support relations are tested as the relations between two regions, viz. circles, and they are not directly constrained by functional information, such as shape, material, and purpose of use. To our knowledge, this is among the first studies exploring containment and support in a geometric framework.

Third, previous studies dealing with the topological prepositions focus mainly on English or other more common languages such as French or German. Inflectional languages have received less attention with some exceptions such as ancient and Modern Greek (resp. Luraghi, 2003, and Landau et al., 2016), Polish (Przybylska, 2002), Croatian (Šarić, 2008; Dinković and Gros, 2018). We examine spatial relations in two Baltic languages that in this respect are rather underexplored.

\section{The Baltic languages: features of expressing spatial relations}

The only alive Baltic languages, Lithuanian and Latvian, stem from Indo-European language family and belong to the Eastern-Baltic branch. The Prussian language, a member of Western-Baltic branch, is fully extinct. Although Lithuanian and Latvian are highly related inflectional languages, they are also divergent in many aspects which is determined by both language internal and external factors. In spite of the geographic neighbourhood, over the time Lithuania and Latvia underwent different cross-linguistic contacts (Lithuanian was more influenced by Slavonic languages while Latvian - by Fennic and German) resulting in significant grammatical differences. Such differences are attested in the expressions of spatial cognition too.

Spatial information in the Baltic languages is expressed by various open-class and closed-class (Talmy, 2000a, 178f.) means: nouns, adjectives, verbs, adverbs, demonstratives, adpositions, cases (Locative in both languages and Instrumental in Lithuanian), word-formation affixes (prefixal and suffixal derivation) (for the overview see Žilinskaitė-Šinkūnienė et al., MS). Prepositions are studied most extensively and diversely: there are descriptive studies with dialectal and diachronic orientation (Fraenkel, 1929; Endzelīns, 1971[1905]; Nītina 1978), componential analyses (Kilius, 1977; 1980), prescriptive accounts (Šukys, 1998), overviews in academic grammars (Ulvydas et al., 1976; Sokols et al., 1959) and contemporary grammars (Ambrazas (Ed.), 1997, Auziņa et al., 2013), cognitive analyses (Šeškauskienė, 2003; Stasiūnaitè and 
Šeškauskienė, 2004; Mikulskas, 2009; Šeškauskienė and Žilinskaitė-Šinkūnienė, 2015; Šķilters and Raita, 2015; 2016). Syntactic synonymy of cases and prepositions in spatial and temporal domains in Lithuanian is addressed by Valiulyte (1998). Semantic and syntactic features of Latvian ambipositions are the main focus of Lagzdina (1997), ambipositions, circumpositions and postpositions - Holvoet (1993, 2001, 2011). Crosslinguistic studies account for the data of the Baltic languages in relation to lexicalization patterns (e.g. Wälchli, 2001a; 2001b; Wiemer, 2013) or syncretism of locational and directional cases (Zaika, 2016). All the previous research on spatial expressions in the Baltic languages is based on corpus, lexicographic, dialectal or historical data, but no experimental methodology has been applied until now.

Prepositions governing case marked nominals have received most attention since they are the main means for expressing spatial relational situations and cover both domains of location and motion. Prepositions, ambipositions and cases that express basic topological and geometric domains of interior, support, proximity, middle region, betweenness and encirclement are listed in Table 1.

Table 1. Spatial prepositions, ambipositions and cases for static spatial relations

\begin{tabular}{|c|c|c|}
\hline $\begin{array}{l}\text { SPATIAL } \\
\text { CONCEPT }\end{array}$ & Lithuanian & Latvian \\
\hline CONTAINMENT & $\begin{array}{l}\text { The Locative case, } \\
\text { [viduj + Gen.] 'inside' }\end{array}$ & $\begin{array}{l}\text { The Locative case, } \\
{[\text { iekš }+ \text { Gen. }]}\end{array}$ \\
\hline MIDDLE REGION & {$[\operatorname{vidur}(y)+$ Gen.] } & \\
\hline $\begin{array}{l}\text { SUPPORT-FROM- } \\
\text { BELOW }\end{array}$ & [ant + Gen. $]$ & {$[u z+$ Gen. $]$} \\
\hline PROXIMITY & $\begin{array}{l}\text { prie }+ \text { Gen.], [šalia }+ \\
\text { Gen.], [greta }+ \text { Gen.], } \\
\text { [ties + Instr.], [pas }+ \text { Acc. }]\end{array}$ & $\begin{array}{l}\text { [pie + Gen.], } \\
\text { [blakus + Dat.], } \\
\text { [līdzās + Dat.] }\end{array}$ \\
\hline BETWEENNESS & {$[\operatorname{tarp}+$ Gen. $]$} & {$[$ starp + Acc. $]$} \\
\hline ENCIRCLEMENT & $\begin{array}{l}{[\text { aplink }+ \text { Acc. }],} \\
{[\text { apie }+ \text { Acc. }]}\end{array}$ & $\begin{array}{l}{[a p+\text { Acc. }]} \\
{[a p k \bar{a} r t+\text { Dat. }]}\end{array}$ \\
\hline SUPERIOR & {$[$ viřs + Gen. $]$} & [virs + Gen. $]$ \\
\hline INFERIOR & {$[p o+$ Instr. $]$} & {$[$ zem + Gen. $]$} \\
\hline
\end{tabular}

Prepositions in Lithuanian are the predominant means to express spatial relations, but in Latvian, in addition to prepositions, ambipositions (e.g., blakus, līdzās, apkārt in the Table 1), circumpositions (Holvoet, 1993, 140) and postpositional local phrases (Holvoet, 1993, 137-139) are used. Latvian ambipositions are also called relational nouns (Lagzdina, 1997, 193) and they always take the Dative which appears either postpositionally or prepositionally (es dzīvoju mežam blakus / blakus mežam 'I live next to the forest'). According to Holvoet $(1993 ; 2011)$, the government of the Dative

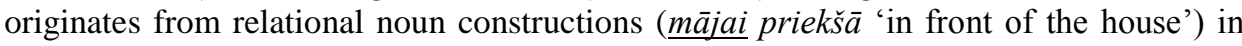
which dativus sympatheticus appears instead of possessive genitive (mājas priekša 'idem').

As it can be seen from the Table 1, Baltic prepositions govern different case forms. Lithuanian prepositions combine with the same case both in singular and plural, but in Latvian, in spite of various possible cases in singular, all prepositions require the Dative plural. This fact was triggered by the demise of the Instrumental case in Latvian. In singular, Latvian Instrumental merged with the Accusative which lead to uncertainty of 
prepositional governing in plural till the Instrumental was preferred after prepositions for systemic reasons. When the Instrumental plural merged with the Dative, the Dative firstly appeared with the prepositions that required the Dative or Accusative in singular, but gradually became generalized also with the Genitive prepositions in plural (Endzelīns, 1951, 632-635).

In addition to prepositions, both languages are equipped with the Locative case since containment relations in Lithuanian and Latvian are rendered, first and foremost, with the Locative. In (1), the Figure-objects are included in a prototypical 3-dimensional Ground-object which functions as a container capable of topological inclusion.

(1) $\mathrm{LT}$

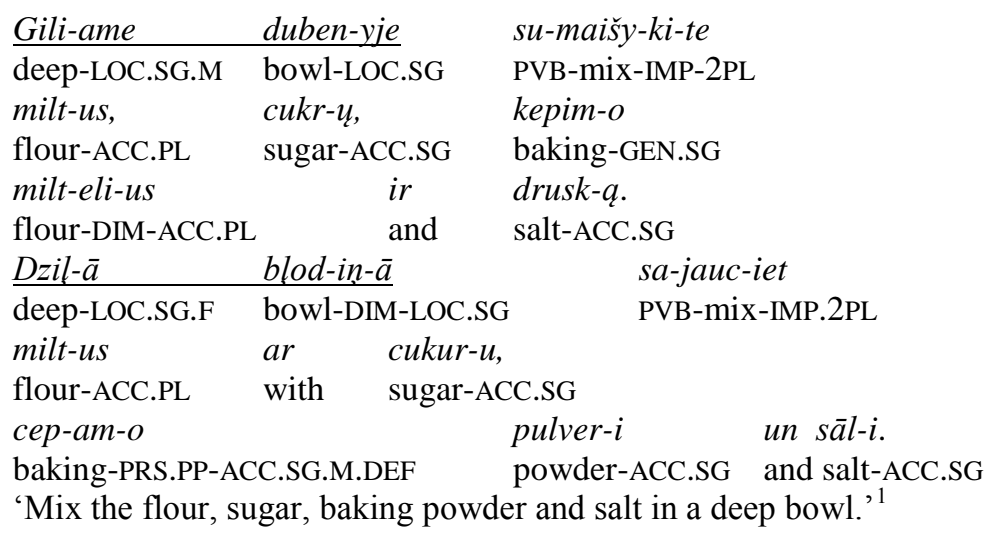

Rarely, the containment is rendered with the prepositions LT viduj resp. LV iekš 'inside' with the Genitive which stem from the spatial nominals vidus and iekša (< illat. iekšan, Karulis, 1992, 334) 'interior'. In Latvian, this construction is also called a prepositional Locative (Rūkse, 1965, 3), but nowadays it is considered stylistically marked (Auziña et al., 2013), cp. examples 2 and 3:

(2) LT

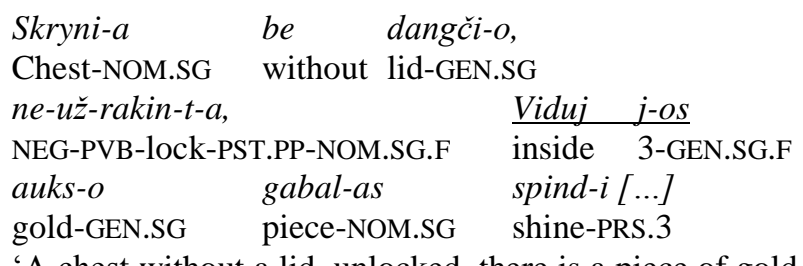

'A chest without a lid, unlocked, there is a piece of gold shining inside of it.'

(3) LV
Ak, sald $-\bar{a}$
oh sweet-NOM.SG.F.DEF
dzērien-a, $\quad k$-as
$o g-a$
drink-GEN.SG INT-NOM
berry-NOM.SG
uz-sit
iekšs $\quad j \bar{u} s-u$
in 2PL-GEN
asin-is.
'Oh, sweet berry in your drink, which heats the blood.'

\footnotetext{
${ }^{1}$ The data has been collected from the Lithuanian-Latvian-Lithuanian parallel corpus (LILA); several examples are taken from fiction by contemporary Latvian writer Svens Kuzmins.
} 
In addition to these spatial grams ${ }^{2}$ provided in Table 1 , lexical means may also appear in Locative case and thus indicate location in the inner region of the Ground. Such lexical means are spatial or relational nominals. The Locative of LT vidus 'interior, inside' and LV iekšpuse 'inner side' express the location inside the Ground. In (4), it is the inner region of the station. In (5), LT viduje 'inside' denotes the inside region of the car, but in corresponding Latvian sentence the Locative case is chosen to convey the same meaning.

(4) LT

\begin{tabular}{|c|c|c|c|}
\hline$J-i e$ & turëj-o & lauk-ti & geležinkeli-o \\
\hline 3-NOM.PL.M & have-PST.3 & wait-INF & railway-GEN.SG \\
\hline stot-ies & vid-uje. & & \\
\hline station-GEN.SG & interior-LOC.SG & & \\
\hline$V i n g-i$ & gaid $\bar{l}-\check{s}$-ot & dzelzcel-a & stacij-as \\
\hline 3-NOM.PL.M & wait-FUT-EVD & railway-GEN.SG & station-GEN.SG \\
\hline $\bar{e} k-a s$ & iekšpus-ē. & & \\
\hline building-GEN.SG & inner.side-LOC.S & & \\
\hline
\end{tabular}

(5) LT

\begin{tabular}{|c|c|c|}
\hline $\begin{array}{l}\text { Automobili-o } \\
\text { car-GEN.SG }\end{array}$ & $\begin{array}{ll}\frac{v i d-u j e}{\text { interior-LOC.SG }} & \text { ras-t-i } \\
\text { find-PST. }\end{array}$ & PP-NOM.PL.M \\
\hline $\begin{array}{l}\text { technini-ai } \\
\text { technical-NOM.PL. }\end{array}$ & $\begin{array}{l}\text { dokument-ai, } \\
\text { document-NOM.PI }\end{array}$ & $\begin{array}{l}\text { rakt-ai... } \\
\text { key-NOM.PL }\end{array}$ \\
\hline Automobil-ī & at-ras-t-i & tehnisk-ie \\
\hline $\begin{array}{l}\text { car-LOC.SG } \\
\text { dokument-i, } \\
\text { document-NOM. }\end{array}$ & $\begin{array}{c}\text { find-PST.PP-NOM.PL.M } \\
\text { atslēg-as... } \\
\text { key-NOM.PL }\end{array}$ & technical-NOM.PL.M.DI \\
\hline
\end{tabular}

Lithuanian viduje 'inside' is also used for "locating" the emotional states in human's inner world (6). The Locative case also may appear in such contexts (7), but it is not common. Moreover, it is not considered grammatical in prescriptive tradition. In Latvian, on the contrary, the usage of the Locative case is not constrained by the feature of animacy, cp.:

(6) LT

LV

\section{Svarbi-ausi-as} important-super-NOM.SG.M plyt-i-nt-is extend-PRS-PA-NOM.SG.M

\section{Galven-ais} main-NOM.SG.M.DEF atrod-as be.located.PRS-3.RFL 'Most important is a deportation camp extending inside a humanbeing.'

\footnotetext{
${ }^{2}$ The term spatial gram is used as in Svorou, 1994, 31. It denotes any grammatical element which expresses spatial meaning.
} 
(7) LT

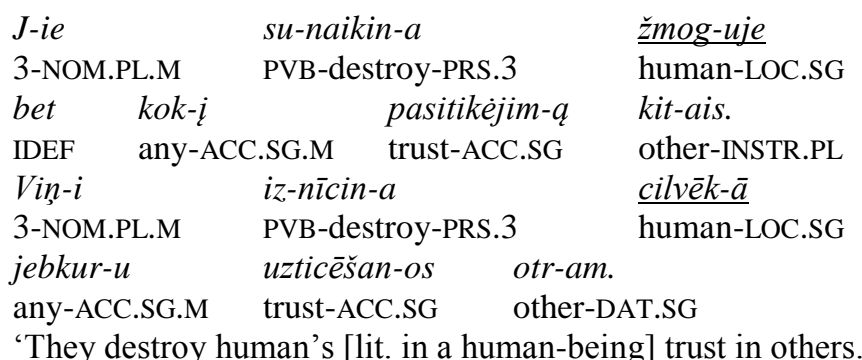

When the Ground object is implicit, the adverbs LT viduje, LV iekšă 'inside' are used:

(8)

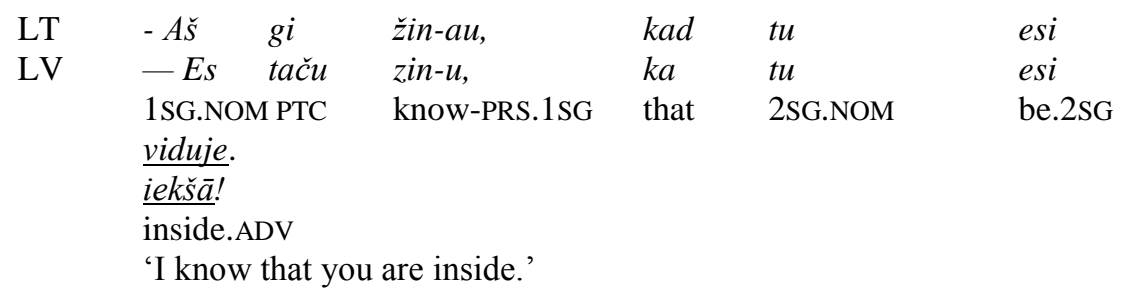

If the location in the middle region of the Ground is specified, several phrases are possible. Preposition LT [vidur(y) + Gen.] 'in the middle' and the Locative case of spatial nominals or relational nouns LT vidurys / LV vidus 'middle, midst' are used (cp. examples 9 and 10). LT viduryje and LV vidu 'in the middle' may function as adverbs as well. Location in the centre region of the Ground is rendered with the Locative case form of the spatial nominal LT centras / LV centrs 'centre', namely, centre / centrā (11).

(9) LT

$$
\begin{array}{lll}
\text { J-ie } & \text { su-sto-dav-o } & \text { vidur } \\
\text { 3-NOM.PL.M } & \text { PVB-stop-HAB-PST.3 } & \text { middle.PREP }
\end{array}
$$

aikšt-es $[\ldots]$

Viñ-i mēdz ap-stā-tie-s laukum-a

3-NOM.PL.M be.used.to.PRS.3 PVB-stop-INF-RFL square-GEN.SG

vid- $\bar{u}[\ldots]$

middle- LOC.SG

'They used to stop in the middle of the square.'

(10) LT

Tik staig-a mini-a su-si-spieči-a rat-u,

PTC suddenly-NA crowd-NOM.SG PVB-RFL-run-PRS.3 circle-INSTR.SG

kuri-o vidur-yje gul-i žmog-us.

which-GEN.SG middle-LOC.SG lie-PRS.2SG human-NOM.SG

LV Te piepeš- $i \quad$ sa-skrien lok- $\bar{a}$,

here suddenly-ADV PVB-run.PRS.3 circle-LOC.SG

$\begin{array}{llll}\text { kur-a } & \text { vid-u } u \text { gul cilvēk-s. }\end{array}$

which-GEN.SG middle-LOC.SG lie.PRS.3SG human-NOM.SG

'And suddenly the crowd runs into a circle, in the middle of which lies a human being.' 
(11) LT

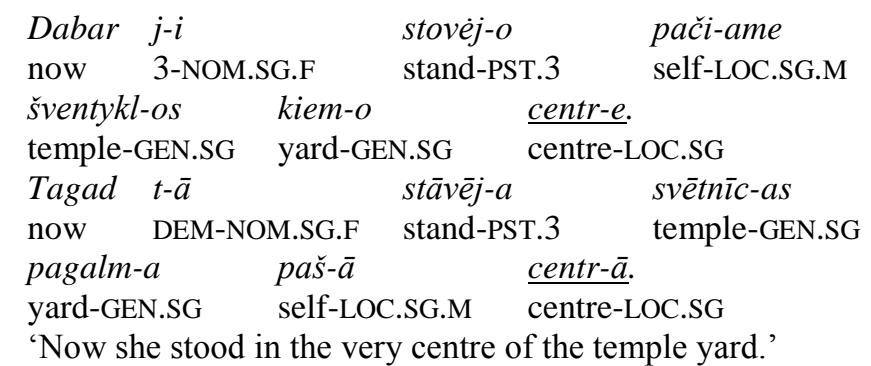

Canonical support situations of horizontal support, when the Figure and the Ground are on the vertical axis and the Figure is supported by the Ground from below, are rendered by the preposition LT ant and LV $u z$ 'on' (12).

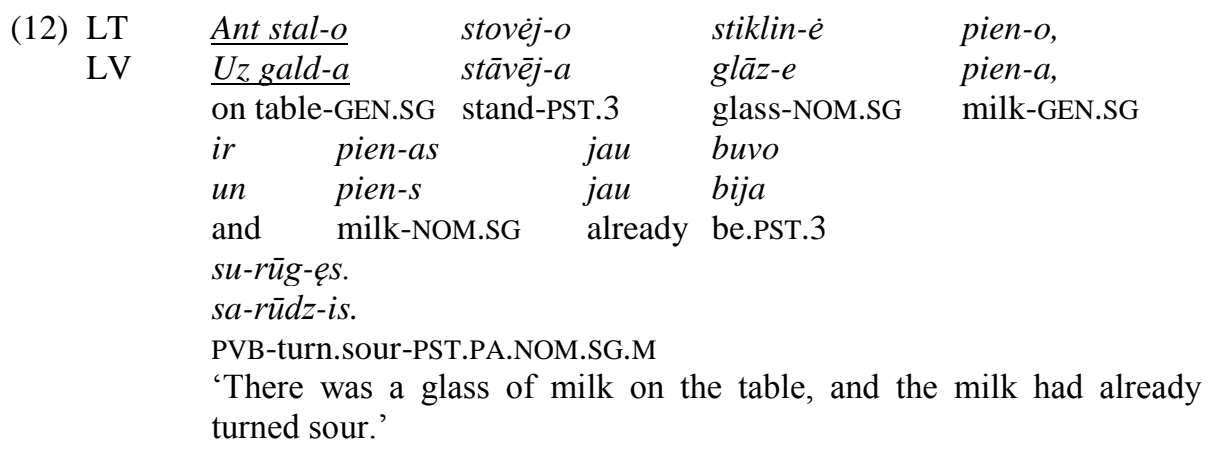

Stasiūnaitè and Šeškauskienè assume that such a prototypical usage of Lithuanian ant is primarily linked to support feature whereas contact, surface and contiguity are rather the outcomes of support $(2004,1-7)$. However, the support domain is very diverse (Levinson and Wilkins, 2006; Gentner and Bowerman, 2009; Landau et al., 2017) and it seems that Lithuanian ant is omnifunctional since it may also cover all the other possible types of support: vertical support, adhesion, hanging, attachment (point-attachment, attachment by piercing and by cord), encirclement with contact, embeddedness. Latvian, on the contrary, exhibits a high variation in expressing these sub-domains because it may employ the prepositions [pie + Gen.] 'at', [ap + Acc.] and the Locative case. The heterogeneity of support domain has not been thoroughly studied in Latvian and this remains one of the future focuses of our research.

Spatial grams listed in Table 1 mainly convey the region of the Ground in which the Figure is located. Nevertheless, spatial grams are only one of the multiple means for the expression of spatial meaning. According to Talmian typology of lexicalization patterns or motion events (Talmy, 1985), which is based on translational motion (Talmy 2000b, 25f.) or transposition (Talmy, 2000a, 181), the Baltic languages are satellite-framed since the path element is usually encoded in the verbal satellite but the meanings of location / motion and co-event (manner or cause) are conveyed by the verbal slot, cp. Latvian example (13): 
(13) LV

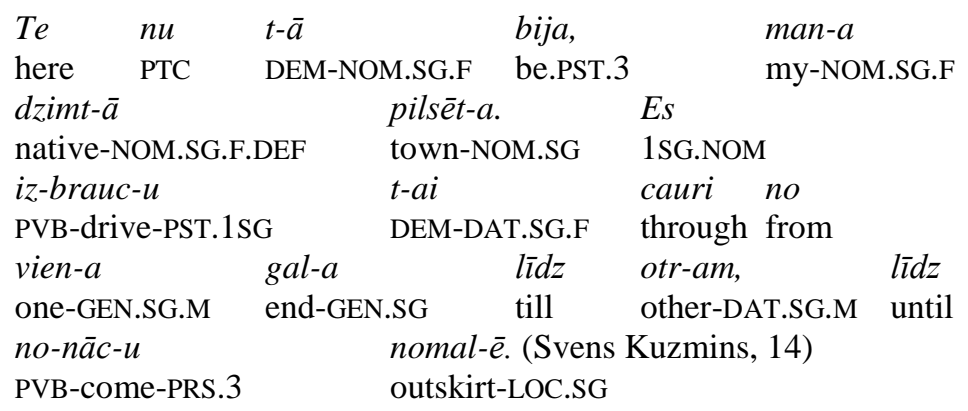

'Here it was, my native town. I drove through it from one end till the other until I reached the outskirts.'

In (13), the verb braukt 'go, drive' indicates motion. Latvian nākt 'come' additionally conveys the path in verbal stem, because this verb is of Finnic structure (Wälchli, 2001b, 414). Otherwise the path element appears in the verbal satellite (verbal prefixes iz-braukt, no-nākt) or adnominally (ambiposition [cauri + Dat.], prepositions $[n o+$ Gen.] and [līdz + Dat.], the Locative case nomalē $)$.

In static contexts, the verb LT büti, LV būt 'be' is used in the basic locative construction (Levinson, 2006), but Latvian is also equipped with the verb atrasties 'be located' which primarily indicates the location of the Figure both in small-scale and large-scale spatial scenes, cp. (14) and (15). Posture verbs LT stoveti, guleti resp. LV stāvèt, gulēt 'stand, lie' (ex. 12) may also occur in both languages, but they are rather optional (cp., Lemmens, 2002; Ameka and Levinson, 2007).

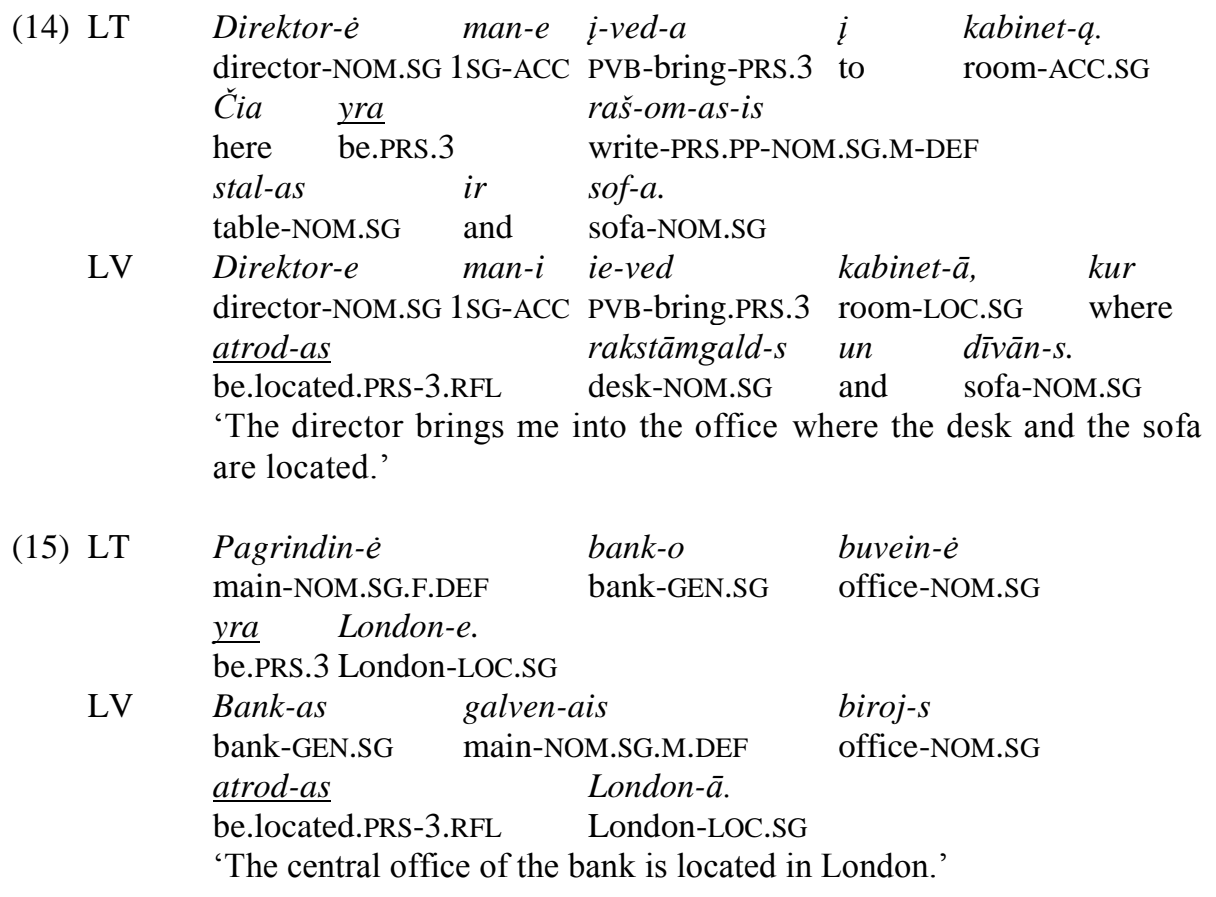


The previous examples show that in the Baltic languages there is no single linguistic form class capable of accumulating the spatial meaning. Conversely, different linguistic elements (adpositions, adverbs, verbal particles, verbs, preverbs) contribute to the expression of spatial scenes exhibiting the principle of distributed spatial semantics (Sinha and Kuteva, 1994).

\section{Extended version of $\mathrm{RCC}$ as a formalism for expressing spatial relations in natural languages}

Within the frameworks of qualitative spatial reasoning a prominent place takes RCC (Randell et al., 1992) assuming a set of core topological relations that can be used for expressing variety of relational spatial information. There are several attempts to apply RCC to natural language analysis (Mani and Pustejovsky, 2012; Rodrigues et al., 2017; Vasardani et al., 2017).

If $x, y$ and $z$ are arbitrary spatial regions, then according to the classical RCC, there are the following relations expressed in a first-order language:

1. Connectedness $C(x, y)$ with the meaning ' $x$ connects to $y$ '

2. Disconnectedness: $D C(x, y) \equiv_{\text {def }} \neg C(x, y)$

3. Part: $P(x, y) \equiv_{d e f} \forall z[C(z, x) \rightarrow C(z, y)]$

4. Proper part: $P P(x, y) \equiv_{\text {def }} P(x, y) \wedge \neg P(y, x)$

5. Overlap: $O(x, y) \equiv_{\text {def }} \exists z[P(z, x) \wedge P(z, y)]$

6. External connectedness: $E C(x, y) \equiv_{\text {def }} C(x, y) \wedge \neg O(x, y)$

7. Partial overlap: $P O(x, y) \equiv_{\text {def }} O(x, y) \wedge \neg P(x, y) \wedge \neg P(y, x)$

8. Equality: $E Q(x, y) \equiv_{\text {def }} P(x, y) \wedge P(y, x)$

9. Discreteness: $D R(x, y) \equiv_{\text {def }} \neg O(x, y)$

10. Tangential proper part: $T P P(x, y) \equiv_{\text {def }} P P(x, y) \wedge \exists z[E C(z, x) \wedge E C(z, y)]$

11. Non-tangential proper part: $\operatorname{NTPP}(x, y) \equiv_{d e f} P P(x, y) \wedge \neg \exists z[E C(z, x) \wedge E C(z, y)]$

Inverse relations to some of the mentioned ones are possible:

12. $P i(x, y) \equiv_{\text {def }} P(y, x)$

13. $\operatorname{PPi}(x, y) \equiv_{\text {def }} \operatorname{PP}(y, x)$

14. $\operatorname{TPPi}(x, y) \equiv_{\text {def }} \operatorname{TPP}(y, x)$

15. $\operatorname{NTPPi}(x, y) \equiv_{\text {def }} \operatorname{NTPP}(y, x)$

In respect to natural language analysis, the canonical version of RCC seems to be too robust because it lacks geometric operators such as distance, orientation, and convexity that are important in representing natural language expressions of space.

Also, object or shape information seems to have impact on the understanding of spatial relations. This is the motivation of an extended framework (Škilters et al., MS) that can be implemented in natural language understanding systems but also in other type of more fine-grained systems of spatial cognition.

Additional extension of the initial RCC formalism concerns the semantic prominence that is assigned to the objects involved in the spatial relation: the object that is under consideration is usually entitled the Figure or central object, whereas the object that 
enables to locate the former object is the Ground or reference object (Talmy, 2000): $R(F, G)$; in our case we initially use all RCC relations (i.e., $R(F, G): R \in R C C$ ).

\subsection{Containment and support in $\mathrm{RCC}+\mathrm{F}$}

Although an extensive axiomatic framework where $\mathrm{RCC}+\mathrm{F}$ extensions are defined is provided elsewhere (Šksilters et al., MS), we will introduce some operators necessary for describing containment and support. We assume that several types of containment exist in real life and correspond to extended RCC relations that are mentioned below.

Closed containment:

A Figure object is inside a solid closed object (container; Ground) such that it cannot come out of it even if the container is moved with it (cp. Davis et al., 2017), e.g. a jam is in a closed jar.

Open containment:

1. The Figure is contained by an upright (vertical) container that is not closed, e.g. an apple in a bowl.

2. The Figure is contained by a vertical container that is not closed and exceeds it, e.g. a flower in a vase.

3. The Figure is contained by a horizontal container that is not closed, e.g. a bus in a tunnel.

4. The Figure is contained by a horizontal container that is not closed and exceeds it, e.g. a cigarette is in the mouth.

The first and the second type of open containment are in virtue of support and are the typical cases of containment even if the Figure is partially geometrically outside of the Ground (container) area. The third and fourth cases are rare and rather exceptional.

Additional geometrical principles necessary for expressing containment are:

1. Convexity. According to Cohn et al. (1997, 287ff.) convex hull operator enables to express at least three geometric (not topological) possibilities of insideness in virtue of their convexity/concavity: if $x$ is an arbitrary Figure region and $y$ is an arbitrary Ground region, then

a. convex inside: $\operatorname{inside}(x, y) \equiv_{\text {def }} D R(x, y) \wedge P(x, \operatorname{conv}(y))$, which can be illustrated with the spatial scenes like an apple in a bowl, shoes in a box etc.;

b. $\quad$ partially convex inside: $p_{-}$inside $(x, y) \equiv_{\text {def }} D R(x, y) \wedge P O(x, \operatorname{conv}(y))$; e.g., flowers in a vase, cigarette in the mouth, stick in one's hand;

c. convex outside: outside $(x, y) \equiv_{d e f} D R(x, \operatorname{conv}(y))$, e.g., an apple in a bowl, but on the top of the other apples and thus outside the inner region of the bowl.

2. Axial structure: verticality, horizontality or obliqueness of overall positioning of regions or objects (can be expressed in one-place predicate):

$\operatorname{VERTICAL}(\mathbf{z})$ or HORIZONTAL(z), or $\operatorname{OBLIQUE}(\mathbf{z})$, where $\boldsymbol{z}$ is a different type of variable indicating and representing alignment of objects or regions.

Containment generates a hierarchy where stronger and weaker relations can be distinguished. Containment typically (i.e. as closed containment) occurs in case of $\operatorname{TPP}(F, G)$ or $\operatorname{NTPP}(F, G)$. These would be the cases of containment that operate both 
topologically and geometrically and are the strongest and correspond to the closed containment. Less strong but still frequently perceived are the open containment cases where the container is vertical (therefore, $\operatorname{VERTICAL}(\boldsymbol{z})$ is applied) and one of the convexity operators apply. Containment is perceived because of support (which in its turn operates because of gravity).

Additional operator supporting containment in cases of verticality is $\operatorname{OVER}(F, G)$ which in turn is one of the qualitative orientation operators (ORIENT) (Mani and Pustejovsky, 2012; Della Penna et al., 2017; for a more detailed description cp. Škilters et al., MS):

1. $\operatorname{UNDER}(F, G), \operatorname{OVER}(F, G)$;

2. TO_THE_RIGHT_OF $(F, G)$, TO_THE_LEFT_OF $(F, G)$;

3. IN_FRONT_OF $(F, G), \operatorname{BEHIND\_ OF}(F, G)$;

4. NEXT_TO $(F, G)$.

UNDER and OVER typically operates on the vertical axis (VERTICAL $(\boldsymbol{z}))$, whereas TO_THE_RIGHT_OF $(F, G), \quad$ TO_THE_LEFT_OF $(F, G), \quad$ IN_FRONT_OF $(F, G)$, $\operatorname{BEHIND} \mathrm{OF}(F, G)$, and $\operatorname{NEXT}_{-} \mathrm{TO}(F, G)$ on the horizontal axis (HORIZONTAL $\left.(z)\right)$. Oblique positions (OBLIQUE(z)) might eventually decrease the strength of support relations.

If inside $(F, G)$ or $p_{\text {_inside }}(F, G)$, or outside $(F, G)$ is combined with $\operatorname{VERTICAL}(\mathbf{z}), \operatorname{OVER}(F, G)$, containment can be perceived because of gravity enabling support that operates between $F$ and $G$.

Additional operator emphasizing the containment is qualitative relation of proximity expressible in two operators: $\operatorname{NEAR}(F, G)$ and $\operatorname{FAR}(F, G)$ (Mani and Pustejovsky, 2012; Della Penna et al., 2017).

A strong case of containment is in the situation where $\operatorname{inside}(F, G)$ or p_inside $(F, G)$, or outside $(F, G)$ is combined with $(\operatorname{VERTICAL}(z)), \operatorname{OVER}(F, G)$, or $\operatorname{NEAR}(F, G)$ (or all three together since the weak disjunction is used), i.e.

$$
\begin{gathered}
\text { containment }(F, G) \equiv_{\text {def }} \\
\left(\operatorname{TPP}(F, G) \dot{\vee} \operatorname{NTPP}(F, G) \dot{\vee} \operatorname{inside}(F, G) \dot{\vee} p_{-} \text {inside }(F, G) \dot{\vee} \text { outside }(F, G)\right) \\
\wedge(\operatorname{VERTICAL}(\mathbf{z}) \vee \operatorname{OVER}(F, G) \vee \operatorname{NEAR}(F, G))
\end{gathered}
$$

where " $\mathrm{V} "$ means the strong (exclusive) disjunction, " $\mathrm{V} "$ - the weak (inclusive) disjunction, and " $\wedge$ " - conjunction.

Finally, the weakest, rather untypical cases of containment are open horizontal containments.

Although topologically one or more RCC principles are used in all of the varieties of containment, in all other cases except (1) they are not crucial and can vary substantially. In the case (1) the topological principles are crucial whereas (2)-(5) geometric principles of convexity are determining. For an overview cp. Table 2. 
Table 2. Types of containment

\begin{tabular}{|c|c|c|c|}
\hline & $\begin{array}{l}\text { Topo- } \\
\text { logic } \\
\text { core } \\
\text { princi- } \\
\text { ples }\end{array}$ & Geometric core principles & $\begin{array}{l}\text { Typical co-occurring or } \\
\text { emphasizing principles } \\
\text { (one or more applies; } \\
\text { the more principles used } \\
\text { the stronger effect) }\end{array}$ \\
\hline $\begin{array}{l}\text { (1) Closed } \\
\text { containment }\end{array}$ & $\begin{array}{c}N T P P \\
(F, G) \\
T P P \\
(F, G)\end{array}$ & & \\
\hline $\begin{array}{l}\text { (2) Open } \\
\text { vertical } \\
\text { containment } \\
\text { and support }\end{array}$ & & $\begin{array}{c}\operatorname{inside}(x, y) \equiv_{\text {def }} D R(x, y) \wedge P(x, \operatorname{conv}(y)) \\
\operatorname{VERTICAL}(\mathbf{z})\end{array}$ & \\
\hline $\begin{array}{l}\text { (3) Open } \\
\text { vertical } \\
\text { containment } \\
\text { and support } \\
\text { (F exceeds } \\
\text { G) }\end{array}$ & & $\begin{array}{c}p_{\text {_inside }}(x, y) \equiv_{\text {def }} D R(x, y) \wedge \\
P O(x, \operatorname{conv}(y)) \\
\text { outside }(x, y) \equiv_{d e f} D R(x, \operatorname{conv}(y)) \\
\operatorname{VERTICAL}(\mathbf{z})\end{array}$ & $\begin{array}{l}\operatorname{OVER}(F, G) \\
\operatorname{NEAR}(F, G)\end{array}$ \\
\hline $\begin{array}{l}\text { (4) Open } \\
\text { horizontal } \\
\text { containment }\end{array}$ & & $\begin{array}{c}\text { inside }(x, y) \equiv_{\text {def }} D R(x, y) \wedge P(x, \operatorname{conv}(y)) \\
\text { HORIZONTAL }(\mathbf{z})\end{array}$ & \\
\hline $\begin{array}{l}\text { (5) Open } \\
\text { horizontal } \\
\text { containment } \\
\text { (F exceeds } \\
\text { G) }\end{array}$ & & $\begin{array}{c}p_{-} \text {inside }(x, y) \equiv_{\text {def }} D R(x, y) \wedge \\
P O(x, \operatorname{conv}(y)) \\
\text { outside }(x, y) \equiv_{\text {def }} D R(x, \operatorname{conv}(y)) \\
\operatorname{HORIZONTAL}(\mathbf{z})\end{array}$ & $\begin{array}{c}\text { TO_THE_RIGHT_OF }(F, G) ; \\
\text { TO_THE_LEFT_OF }(F, G) ; \\
\text { IN_FRONT_OF }(F, G) ; \\
\text { BEHIND_OF }(F, G) ; \\
\text { NEXT_TO }(F, G) ; \\
\text { NEAR }(F, G)\end{array}$ \\
\hline
\end{tabular}

\section{Materials and methods}

\subsection{Task design and procedure}

A set of 31 randomized stimuli displaying 2 objects each (the light circle and the dark circle) situated in different topological and geometrical configurations were prepared as a partially open-ended production task. Fixed tasks (Carlson and Hill, 2003, 270) are not suitable for the Baltic languages because of the rich morphological structure which would lead to constrained responses. The task required to describe the location of the dark circle in relation to the light one. The question "Where is the dark circle?" was asked after each stimulus. In the answer line, only the name of the Figure object "The dark circle" was provided. The data collection was conducted in a paper-and-pencil and a digital task (created in Question Pro platform); each task contained the same set of randomized stimuli. Each set of stimuli was preceded by a brief introduction and an instruction: "please, define the location of the dark circle in relation to the white one" 
and followed by a demographic questionnaire. The descriptive statistics and statistical tests (t-test, ANOVA) were conducted by software SPSS Statistics 22.

\subsection{Stimuli and setup}

The stimuli were prepared according to Region Connection Calculus (RCC; Randell et al., 1992; Cohn et al., 1992) and the extended version of it (RCC+F; Šksilters et al., MS). RCC were represented by the variables that are based on primitive topological relation of connectedness, such as:

1. Disconnectedness $(D C)$, External connectedness $(E C)$, Partial overlap $(P O)$, Tangential proper-part (TPP) and inverted relation of Tangential proper-part (TPPi), Non-tangential proper-part $(N T P P)$ and inverted relation of Non-tangential proper-part (NTPPi).

Additionally, 4 more variables were included:

2. Partial occlusion.

3. Orientation (left, right, above, below, oblique).

4. Proximity (close / far).

5. Size (small / large).

We wanted to have a preliminary overview of how different variables effect the description of the spatial scene and, in addition, how they influence the granularity and length of the responses provided.

In this paper, we analyse 8 support stimuli displaying above/below orientation of the Figure in external connectedness $(1,2)$, partial overlap $(3,4)$ and partial occlusion $(5,6$, $7,8)$ and 5 containment stimuli depicting non-tangential proper-part (centred (11) and oblique (12)), tangential proper part (oblique (13)), and inverse relations of nontangential (14) and tangential proper part (15). They are represented in the tables 3 and 4.

Table 3. Support stimuli

\begin{tabular}{|l|l|l|l|}
\hline 1 & 2 & 3 & 4 \\
\multicolumn{1}{|c|}{8} & 8 & 8 & 8 \\
\hline 5 & 6 & 7 & 8 \\
\hline & 8 & 8 & 8 \\
\hline
\end{tabular}


Table 4. Containment stimuli

\begin{tabular}{|l|l|l|}
\hline 11 & 12 & 13 \\
\hline & & \\
\hline & 14 & \\
\hline
\end{tabular}

\subsection{Participants}

45 participants of each language (Lithuanian and Latvian) filled in the questionnaire as paper-and-pencil task (further - p-task) and 60 Latvian and 61 Lithuanian participants conducted the experiment as a digital task (further $-e$-task). The number of male and female participants was almost equally balanced for the e-task $(52 \%$ women and $48 \%$ men for LV and $51 \%$ women and $49 \%$ men for LT) but with more male participants for the p-task (30\% women and $70 \%$ men for LV and 44\% women and 56\% men for LT).

Almost all the participants were native speakers of Lithuanian or Latvian with English as the second (both Latvians and Lithuanians - 91\%) and Russian as the third (Latvians $-72 \%$, Lithuanians $-56 \%$ ) best known language. In both tasks, 2 LT participants and $3 \mathrm{LV}$ participants indicated Russian as their native language. In the p-task, Yiddish was the mother tongue for $1 \mathrm{LV}$ participant, but in the e-task, other languages as mother tongues were indicated by $1 \mathrm{LT}$ and $2 \mathrm{LV}$ participants.

Most of the participants that filled the e-task were with higher education (Latvians $75 \%$, Lithuanians $74 \%$ ), but the p-task was filled by $37 \%$ Latvian and $36 \%$ Lithuanian participants with higher education. Regarding Latvian participants, the p-task was filled by $11 \%$ participants with secondary school education. Humanities/Social sciences were the most frequent fields of education for both Lithuanian and Latvian respondents in the e-task ( $72 \%$ and $60 \%$ respectively). Most of the participants in the p-task were from the fields of exact sciences; Humanities and Social sciences were represented by $18 \%$ Lithuanian participants and $34 \%$ Latvian respondents. We have also to take into account the amount of respondents with general education who filled the paper task, because they cannot provide information about specialization of education.

The age distribution of Latvians was partly similar in both tasks (p-task/e-task) younger than $25: 41 \% / 30 \% ; 25-34: 23 \% / 27 \% ; 35-44: 16 \% / 23 \% ; 45-54: 9 \% / 8 \%$ and older than 55: $11 \% / 12 \%)$. The sample of Lithuanian participants has a different agedistribution: the p-task was filled by $73 \%$ participants under age of $25,7 \%$ participants were in the age group from $25-34 ; 11 \%$ and $9 \%$ were in the age groups $35-44$ and over 
55. The e-task was filled by $15 \%$ participants younger than 25 , while most respondents were in the age groups 25-34 (44\%) and 35-44 (31\%) while 10\% were older than 55.

Demographic part also included questions regarding age, occupation, and hobbies; the participants also had to indicate the place she/he has spent the most part of life. Electronic task ended with the question about right- / left-handedness (LV: $92 \%$ / 8\% and LT: $95 \%$ / 5\%).

Median time to complete the electronic task was $\sim 14$ minutes for both languages.

\section{Results and discussion}

Although our results do not explore all types of containment and support (for this purpose everyday spatial relations with typical objects are necessary), our results show that minimal topological stimuli with certain geometric extensions induce some significant constraints characterizing support and containment in their linguistic representation.

As already mentioned, the experiment was conducted in two stages: different participants completed a paper-and-pencil and a digital task. We provide the results from both of them (either in the following sequential order results of the p-task / results from the e-task or by naming $p$-task / e-task) and also evaluate the answers according to the length (amount of words used to describe the relation) and precision of the description of the Figure's location. The latter measure was determined according to the granularity of the information provided to describe where the Figure is situated. The criteria for location measure were the following:

1. position of the Figure in relation to the Ground (e.g. various linguistic means indicating that the Figure is located above, below, left, right, inside etc. the Ground);

2. direction (horizontal / vertical / oblique axis, cardinal directions);

3. distance;

4. part of the Ground. If the position of the Figure was described in relation to the certain part of the Ground (edge, side, corner etc.), it was considered as separate criterion increasing the value of location parameter;

5. units specifying the size or degree of distance, overlap or occlusion. Linguistically such information was expressed very differently ranging from vague to very accurate descriptions, namely, from adverbials meaning 'approximately', 'a little', 'tightly' to precise markers or measures, e.g. distance of two diameters;

6. topological verbs as additional location markers. The range of such verbs was very large and they were important means for the description of the Figure's the location.

We took into account the format of the data (discrete, ordinal). However, we decided to use the results of the parametric tests as they coincide with the results of corresponding non-parametric tests that also were conducted. At the same time, parametric tests give a fair impression about the mean values which can be further interpreted for the gradual change comparisons. The average values of the lengths and precision of the descriptions are summarised in the Table 5. 
Table 5. Average values of the amount of words and precision of description in LT and LV responses of both p-task and e-task

\begin{tabular}{l|r|r|r|r|r|r|r|r|r|r|r|r|r|} 
Stimuli & 1 & 2 & 3 & 4 & 5 & 6 & 7 & 8 & 11 & 12 & 13 & 14 & 15 \\
\hline
\end{tabular}

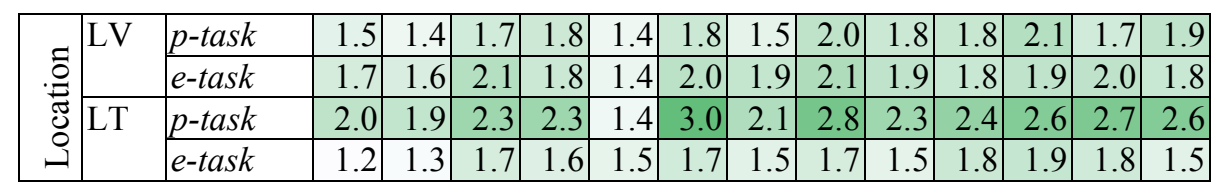

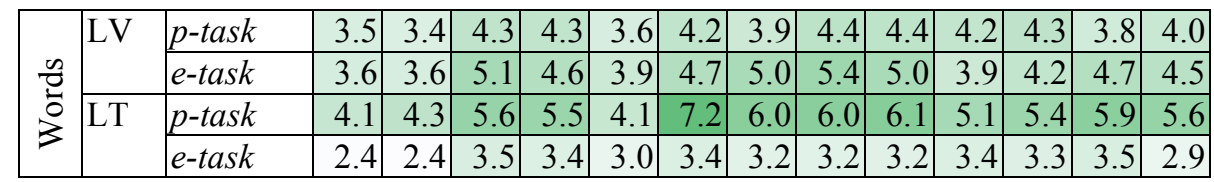

Interestingly, the statistical tests show no significant difference $(\alpha=0.05)$ among electronically and paper-and-pencil data collection methods regarding the length of the answers and precision in description of location in Latvian data. Lithuanian results of paper and electronic tasks, on the contrary, differ significantly. The answers in LT p-task are remarkably longer and rather fine-grained with regard to the description of the Figure's location than in e-task.

If e-task and p-task are considered separately, Lithuanian and Latvian significantly differ in relation to amount of words and granularity of describing the Figure's location. The tendencies regarding different stimuli are reflected in the Tables 5, 6 and 7. Such differences in some cases could be determined by the conditions of the experiment, namely - particular time of completing the task. For example, a significant amount of the p-task questionnaires in both languages was filled in by undergraduate students $(41 \% \mathrm{LV}$ and 73\% LT), but Latvian students accomplished the p-task after the exam which could result in more concise answers than those of Lithuanian students who could take their time and opportunity to edit or supplement their answers due to more relaxed conditions.

Table 6. Amount of words in LT and LV responses of both p-task and e-task

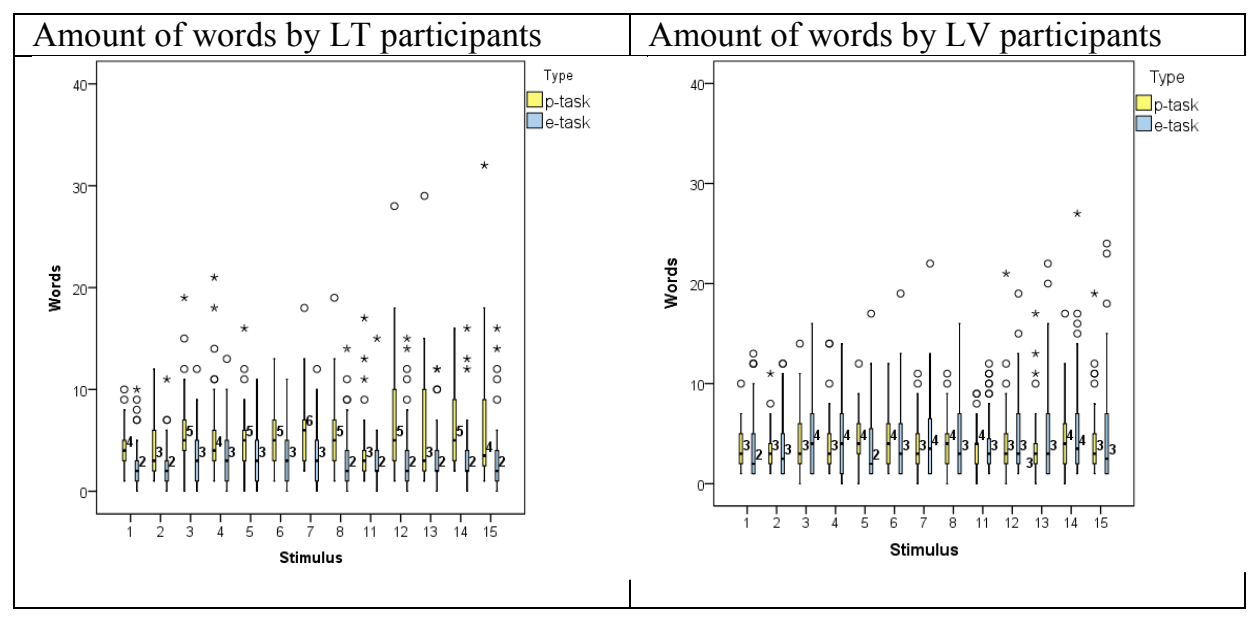


Table 7. Specification of Figure's location in LT and LV responses of both p-task and e-task

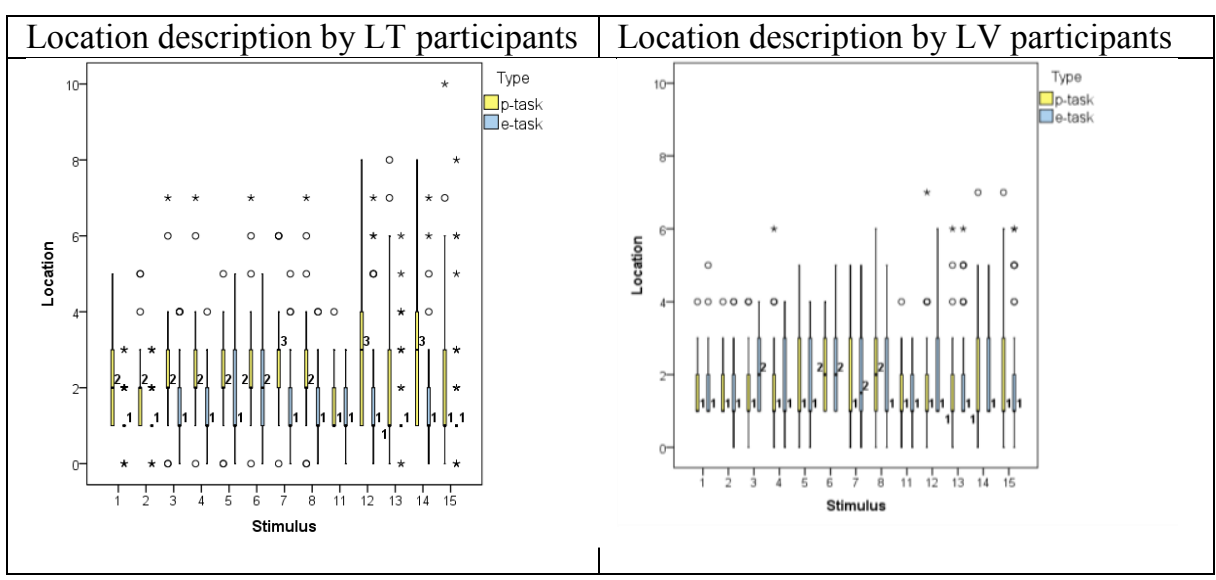

According to our results, support seems to operate in cases of external connectedness and verticality. This is plausible since the main principle underlying spatial relations in everyday situations is gravity which is inherently linked with vertical alignment of spatially (externally) connected objects.

As the most typical cases for support among the geometrical relations we assume those represented by stimuli 1 and 2. The canonical support relation in our stimuli set is the stimulus 1 containing relatively few words in the subjects' responses and not significantly varying in respect to the number of words and description of location among the participants (indicating that it is among the less ambiguous relations which is relatively consistently shared by most of the subjects, see the tables 6 and 7 for the results).

In some of the descriptions relations between Figure and Ground objects indicate relative divergences or asymmetries which might be also in virtue of typical FigureGround alignment relations because of support. If stimuli 1 and 2 are compared we can observe that the canonical support situation (stimulus 1) has a significant amount of descriptions referring to verticality and the upper part of the visual scene (LV virs 'above' 58/50\% ${ }^{3}$, augšā 'up' 27/38\%, and uz 'on' 7\%/- and LT viř̌ 'above' $82 \% / 74 \%$, ant 'on' $7 \% / 15 \%$; see Table 8$)^{4}$. If the reverse relation (2) is observed, the lower part of the vertical alignment emerges with LV zem 'under' 64/50\%, apakš $\bar{a}$ 'below' $18 / 30 \%$, lejā 'down' $16 / 10 \%$ and LT apačioje 'below' 51/56\%, po 'under' 27/28\%, žemiau 'lower' 16\%/- (see Table 8).

Interestingly, in both situations there are answers indicating the Figure's location next to the Ground, namely, LV blakus, klāt, lìdzās and LT šalia, greta, prie pat, prie (stimulus 1: LV 7/8\% and LT 18/-\%; stimulus 2: LV 7/5\%, LT 13/7\%, see Table 8), which as we might hypothesize is a strong effect of proximity and arise not only in situation of horizontal alignment (which seems to be intuitively more plausible) but also in case of vertical alignment.

\footnotetext{
${ }^{3}$ Only the data equal to or exceeding $5 \%$ of usage is included in the analysis.

${ }^{4}$ Here and further the most frequent lexeme of the expressed spatial concept is given (i.e. in addition to augša 'up', other linguistic forms bearing the same meaning like uz augšu, no augšas, augšpus(ē), augšējais also appear).
} 
Table 8. The data of support stimuli, $\%$

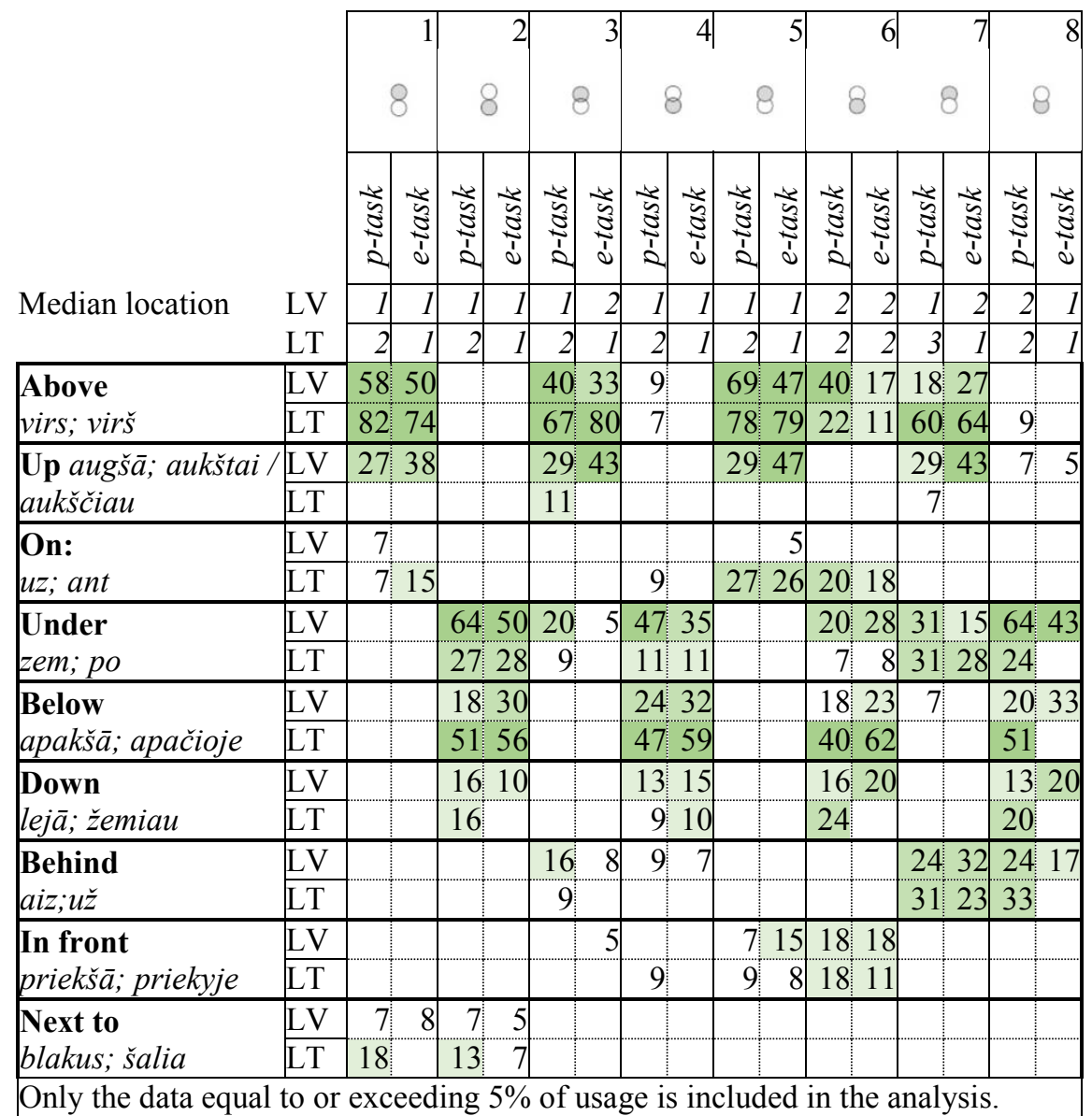

If situations of partial overlap are analyzed (stimuli 3 and 4), in Latvian we can see a somewhat similar pattern with a less explicit role of virs 'above' (40/33\%) but in total indicating strong sensitivity to vertical axis augša 'up' (29/43\%), at the same time less unambiguous - some of the described relations make sense if the stimuli are interpreted 3-dimensionally (20/5\% zem 'below', 16/8\% aiz 'behind', -/5\% priekš $\bar{a}$ 'in front', the last one occurs in electronic task only). Although zem 'below, under' can be interpreted as a special case of support, aiz 'behind' and priekš $\bar{a}$ 'in front' - not. Interestingly, in (3) LV $u z$ ' 'on' does not occur since the Ground is not interpreted as supporting the Figure in the vertical alignment. The combination of the Figure and the Ground (overlap) is interpreted 3-dimensionally emphasizing the order of the circles viewed in horizontal plane (aiz 'behind' and priekša 'in front') or from above (zem 'below, under').

Lithuanian data for stimulus 3 is more homogenous (Table 8). Even though p-data shows almost the same response types as in Latvian enabling the interpretation of both 2dimension vertical alignment and 3-dimensional sequence (viršs 'above' 67\%, aukščiau

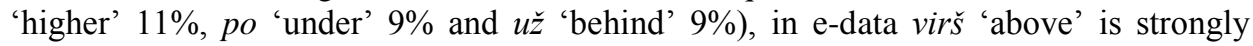
preferred, the upper part of vertical alignment being the focus of the responses $(80 \%$ in 
total, comprising different linguistic forms such as viřs, viršuj(e), $i$ viršu tiesiai viršs, also modifiers like viršutinis 'the one above').

Also, the reverse partial overlap relation (4) in Latvian is less explicit in terms of the core relations: zem 'under' is $47 / 35 \%$, apakša 'below' $24 / 32 \%$, lejā 'down' $13 / 15 \%$ and aiz 'behind' $9 / 7 \%$, virs 'above' $9 /-\%$ (the latter two showing a 3-dimensional interpretation) (Table 8). In Lithuanian, in addition to lower region expressions (apačioje 'below' $59 / 47 \%$, po 'under' $11 / 11 \%$, žemiau 'lower' 9/10\%), the scene is interpreted 3dimensionally from above iš viršaus, virš 'from above, above' $9 \% /$, enabling also support perception: the support preposition ant 'on' 9/-\%, indicates that the Figure object is seen as located on the Ground. LT priekyje, priešais 'in front of' appears in 9/-\% of the cases showing the application of relative frames of reference in horizontal plane.

Various ways to perceive the vertical scenes of partial overlap (stimuli 3 and 4) lead to a larger amount of words in responses compared to the stimuli 1 and 2 depicting the relation of external connectedness only. This indicates that canonical support relation is represented by the stimulus 1 and is less strong and somewhat more ambiguous in other geometrically similar cases. In addition, the responses of stimuli 3 and 4 in both languages and both tasks contain a significant amount of verbs specifying the overlap in relatively precise topological terms (we are calling them 'topological verbs'), e.g. LT verbs persikloti, persidengti 'overlap', persikirsti 'cross over each other', susijungti 'merge', susikloti 'lay over each other', dengti, pridengti, uždengti 'cover', paslinkti 'scroll', ribotis 'border', ịlisti 'get in', palisti 'get under', užlisti 'get behind', užlipti 'climb' and LV verbs šķelt 'split', šksèrsot, krustot 'cross', pārklāt 'overlap', savienot 'combine', saskarties 'connect', pieklauties 'touch' are attested in various forms.

Table 9. Use of verbs for support stimuli, \%

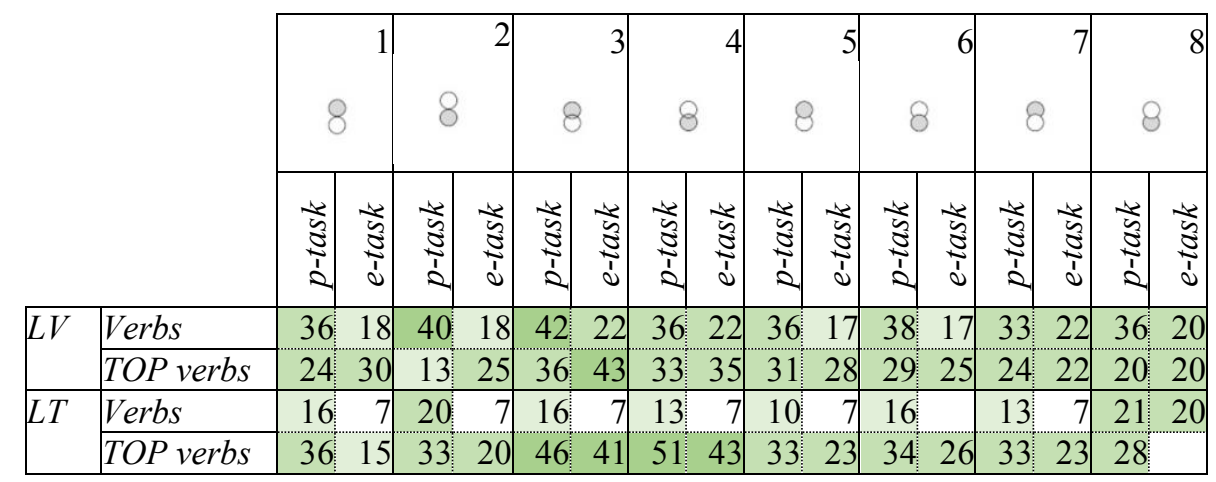

One interesting case is the situation of partial occlusion (5) which is not expressible in canonical RCC and its extensions. In Latvian, there is a significant amount of virs 'above' 69/47\% and augša 'up' 29/47\% showing extremely strong vertical alignment (Table 8). The same applies for Lithuanian data since $78 / 79 \%$ of the answers include expressions indicating above region (virš, viršuj(e), $\dot{l}$ viršu, iš viršaus, tiesiai virš, modifier viršutinis). In some cases, this stimulus is interpreted 3-dimensionally and horizontally employing the relative frame of reference since LV priekš $\bar{a}(7 / 15 \%)$ and LT 
prieš, priešais, priekyje (9/8\%) 'in front of' are attested. Support interpretation in vertical alignment occurs in $27 / 26 \%$ of the cases in Lithuanian (ant 'on', ant viršaus 'on the top'), but in Latvian $u z$ 'on' is rather marginal as it is attested only in $5 \%$ of the responses of e-task.

The reverse relation (6) in Latvian is, however, interpreted differently. P-data shows (Table 8) the interpretation more in respect to viewer's position from above in a threedimensional setting (most of the answers (40\%) indicating virs 'above' but according to the configuration that the Figure object is located on the Ground object). However, in e-data such interpretation is rare $(17 \%)$ but zem 'under' $(28 \%)$ occurs most frequently (two-dimensional vertical alignment). In addition to zem 'under', vertical alignment is also expressed by apakš $\bar{a}$ 'below' (18/23\%) and lejă 'down' (16/20\%). In 18\% of the cases in both tasks this scene is interpreted 3-dimensionally and aligned horizontally employing LV priekša $\bar{a}$ 'in front of'. Lithuanian allows all the interpretations that are found in Latvian (below, under, down, in front, above), the most frequent of them being apačioje 'below' (40/62\%) and referring to the lower part of vertical axis. But in addition to interpretations found in Latvian, it also enables support interpretation as $20 / 18 \%$ of the answers include ant 'on' or ant viršaus 'on the top'.

Possible interpretations of stimuli 7 and 8, depicting the occluded Figure, are similar in both languages. In 7, the focus is both on the upper part of vertical alignment (LV virs 'above' 18/27\%, LT virš, viršuje 'above' 60/64\%, LV augšā 'up' 29/43\%, LT aukščiau 7/- \% 'higher') and three-dimensional setting (LV zem 'under' 31/15\%, LT po 'under' $31 / 28 \%$, LV aiz 'behind' $24 / 32 \%$, LT $u \check{z}$ 'behind' $31 / 23 \%$ ). In 8, the emphasis is put on the lower part of vertical axis enabling also 3-dimensional interpretation (LV zem 'under' 64/43\%, apakša 'below' 20/33\%, lejā 'down' 13/20\%, aiz 'behind' 24/17\%). LV zem 'under' is frequent since it allows both 2 - and 3-dimensional interpretations.

To explore the cases of vertical partial occlusion $(5,6,7,8)$, a separate study is necessary because there might be some significant impacts of the processes of visual amodal completion (cp. Palmer and Neff, 1996; Singh, 2004).

Importantly, in case of stimuli of vertical alignment and $E C, P O$ and partial occlusion, the stimuli 1 and 5 are the instances of the canonical support preposition LV $u z$ resp. LT ant 'on'. In 1, this preposition occurs in LV 7\%/- and LT 7\%/15\% of the cases. In 5, Latvian has only marginal manifestation of the support preposition (-15\%), but Lithuanian has a significant amount of ant 'on' $(27 / 26 \%)$. There are no other situations having more than 5\% Latvian answers containing $u z$ 'on'. Interestingly this is also the case with partial overlap $(3,4)$. Lithuanian, in addition to stimuli 1 and 5, allows support interpretation in certain cases of partial overlap (4) and partial occlusion (6), when the spatial scene is viewed 3-dimensionally from above, thus the Figure is interpreted as put onto the Ground.

Worth mentioning are the other situations that are interpreted three-dimensionally. NTPP (stimulus 11) case (where the Figure object is central) is interpreted as a configuration where the Figure objects is located on the Ground object therefore allowing a support relation (LV $u z$ 'on' is $9 / 5 \%$ resp. LT ant 'on' is 9/10\%) (Table 10). 
Table 10. The data of containment stimuli, $\%$

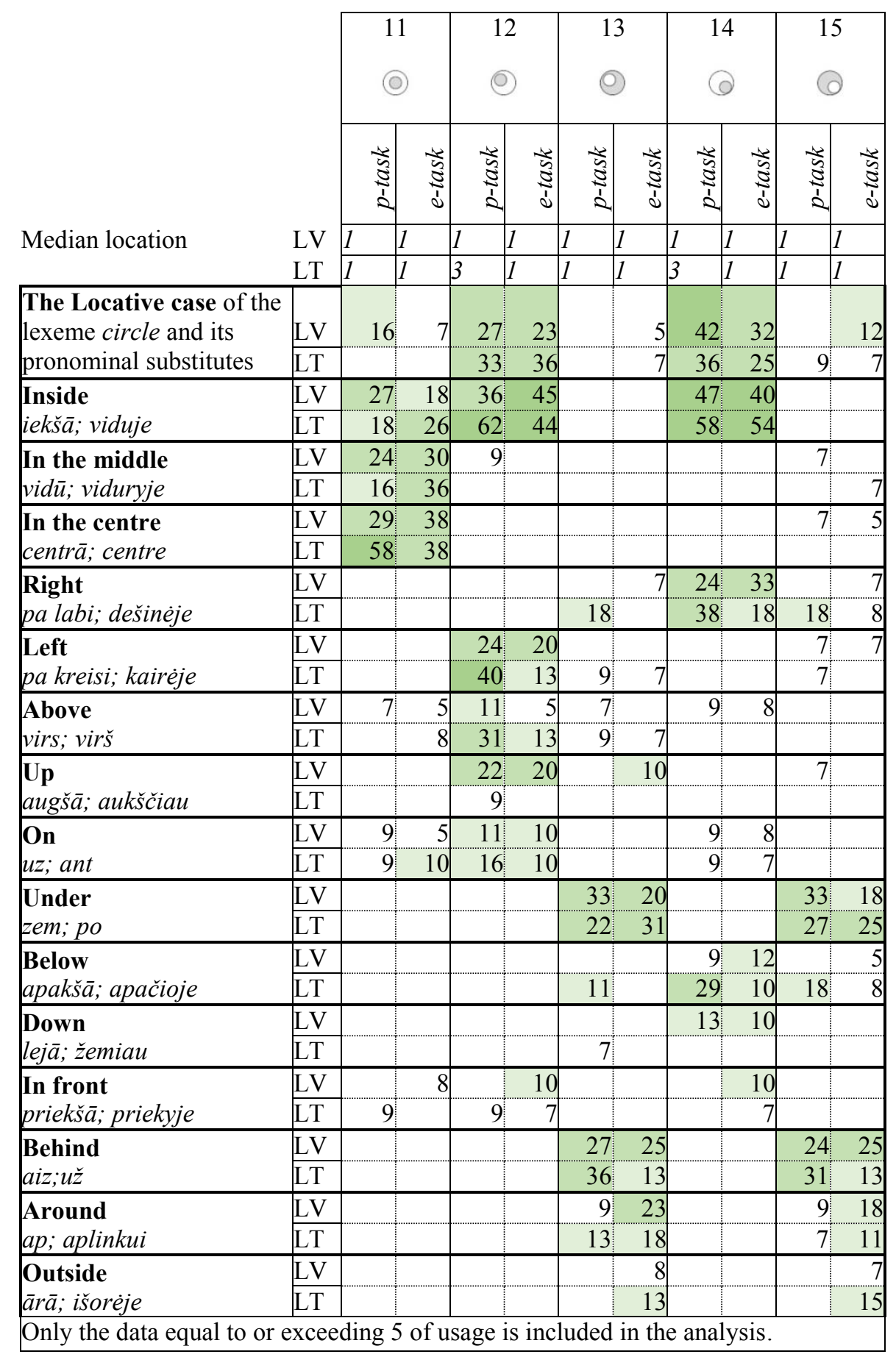


Also, the case of NTPP where the Figure is located on an oblique axis (stimulus 12) indicates some answers representing configuration where the Figure is on the Ground therefore enabling a support-relation (LV $u z$ 'on' is $11 / 10 \%$, LT ant 'on' is $16 / 10 \%$ ). Similarly, in TPP variation (where the Figure is on oblique axis; stimulus 14) - there is substantial part of LV $u z$ 'on' $-9 / 8 \%$ and LT ant 'on' 9/7\%. In the reverse relations (13, 15) there are no LV uz and LT ant 'on' indicating that support relations operate when the Figure is interpreted as an object located on the Ground.

Although LV $u z$ and LT ant 'on' as a significant result of the lexicalizing of support relations appear in the mentioned stimuli, these responses might be also in virtue of ambiguity in respect whether to interpret these relations from above or from the side.

In general, support relation within a geometric framework is highly sensitive to horizontal axis and connectedness relation between Figure and Ground objects (the latter seems to be the case in the interpretations of non-horizontal alignment as in the partial occlusion or overlapping in NTPP and TPP cases).

In case of containment, Locatives are the canonical way of expressing it. Locative constructions seem to be relatively frequent in different types of stimuli. However, in our stimuli containment are the variations of TPP or NTTP.

Stimulus 11 is a specific type of containment as the location in the middle region or centre is specified that is why the centre of the Ground object is crucial. For this reason, the location of the Figure is predominantly described involving spatial nominals denoting the centre or middle region marked in the Locative case: LV centrā $29 / 38 \%$, LT centre $58 / 38 \%$ 'in the centre', LV vidū $24 / 30$, LT viduryje $16 / 36 \%$ 'in the middle'. The inner region may also be explicit: LV iekšā 27/18\% and LT viduj 18/26\% 'inside'. In Latvian, the Locative case of noun aplis 'circle' and its pronominal substitutes occurs $16 / 7 \%$.

$N T P P$ where the Figure is not centred, but is in an oblique location (stimulus 12), and oblique TPP version (stimulus 14) also show a significant number of Locatives, but in the distribution of the Locatives an opposite strategy is observed. First and foremost, the inner region of the Ground is defined by the Locative case marked spatial nominals (LV iekš $\bar{a}$ 36/45\%, LT viduj(e) 62/44\% 'inside' for 12 and LV iekš $\bar{a} 47 / 40 \%$, LT viduj(e) $58 / 54 \%$ 'inside' for 14 ). The inner region is also expressed by the Locative case of nominals referring to the circle or its part: LV 27/23\% and LT 33/36\% for stimulus 12 and LV $42 / 32$ and LT $36 / 25 \%$ for stimulus 14 . Only afterwards the additional information about exact location is specified if specified at all. Usually horizontal or vertical alignment location is indicated: for 12 , it is 'to the left' in LV $24 / 20 \%$ and LT $40 / 13 \%$ or 'up' in LV $22 / 20 \%$ and LT $31 / 12 \%$, for 14 , it is 'to the right' LV $24 / 33 \%$ and LT 38/18\% or 'down' LV 22/22\% and LT 29/10\%). For stimuli 12 and 14, additional information specifying the Figure's location is provided using cardinal directions, directions of clock arrows and topological verbs. Thus the stimuli 12 and 14 have a large variety and difference between answers and have a significant number of answers indicating horizontal-alignment location (it is co-determining). This indicates that the centrality of the Figure (stimulus 11) is an important factor emphasizing the perception of location as expressed in Locative. In addition, stimulus 11 has least words in the responses and, compared to 12 and 14, the location of the Figure is described using least words.

The reverse stimuli (13 and 15) represent the relation of encirclement which is lexicalized in both languages and both tasks: LV ap and LT aplink 'around' occur in $9 \% / 23 \%$ resp. $13 \% / 18 \%$ of the answers for the stimulus 13 and in $9 \% / 18 \%$ resp. $7 \% / 11 \%$ of the answers for the stimulus 15 . In fewer cases the respondents emphasize 
the outside region with LV ārā resp. LT išorëje 'outside' (13: LV -/8\%, LT -/13\% and 15: LV $-17 \%$, LT - $/ 15 \%)$. Nevertheless, the encirclement relation seems not to be as important as the vertical or horizontal axial information. 3-dimensional vertical alignment (namely, LV zem and LT po 'under') occurs in LV 33\%/20\% and LT $22 \% / 31 \%$ of the cases for the stimulus 13 and in LV $33 \% / 18 \%$ and LT $27 \% / 25 \%$ of the cases for the stimulus 15 . The 3-dimensional horizontal alignment is lexicalized with LV aiz resp. LT $u \check{z}$ 'behind' and is attested in LV 27\%/25\% and LT 36\%/13\% of the responses of the stimulus 13 and in LV 24\%/25\% resp. LT 31\%/13\% of the responses for the stimulus 15 . The information about the oblique axis remains marginal for both stimuli.

Interestingly, when describing the reverse relations (13 and 15), some participants choose to describe the location of the dark circle in relation not to the light circle, but, for example, the page (in p-task) or the screen (in e-task): this explains the occurrence of spatial utterances like in the middle and in the centre (see Table 10). The use of the Locative case when describing the stimuli 13 and 15 can be explained by the inversion of the Figure and the Ground: the participants specify the location of the light circle in relation to the dark one instead of the location of dark circle in relation of the light one. Thus, for the stimulus 13 Locatives of the circle lexeme occur LV -/5\%, LT -/7\% and for the stimulus $15-\mathrm{LV}-/ 12 \%$, LT $9 \% / 7 \%$.

The differences between the mentioned spatial relations in 11, 12, 14 and its reverses 13, 15 indicate Figure-Ground dependency in respect to the containment. Also, in case of containment, axial information seems to be crucial since the central case of the location of the Figure generates the clearest pattern of interpretation. And the more oblique the locations of the Figure are, the more answers tend to be different from the Locative. Instead of the Locative, oblique cases are indicating horizontal axial information (such as - to the left of / to the right of).

\section{Conclusions}

Although some discrepancies between the formal model and empirical evidence are existent, the overall pattern seems to be valid. Axial information in general and vertical axial alignment together with the connectedness relation determine the interpretation of the simple topological and geometric support relations but shape also the way containment is perceived and represented in the Baltic languages. Further, the results show some strong similarities (e.g. stimuli 1, 5, 11, 12, 14) and some divergences (e.g. stimuli 4, 6).

In order to enable the interpretation of support, axial information and connectedness are essential. Since support is interpreted either 2-dimensionally or 3-dimensionally, two types of support are distinguished:

From a 2-dimensional perspective, we deal with the canonical vertical alignment with the Figure situated in the upper part. In the cases of vertical alignment (1 and 5), support prepositions (LV $u z$, LT ant 'on') occur rather marginally since the participants focus on the orientation of the Figure in relation to the Ground, but disregard the functional interaction between the Figure and the Ground (which is the relation of support). Instead of support, geometric orientation seems to be impacting, because proximity and connectedness dominate. Proximity terms for stimulus 1 exceed support prepositions even though the Figure and the Ground are in vertical alignment. A significant exception is the stimulus 5 with $27 / 26 \%$ of LT ant 'on' where the support 
interpretation could be determined by the feature of occlusion enabling the perception of interaction between the circles in terms of support. LV preposition $u z$ 'on' for the stimuli 5 occurs only marginally $(-/ 5 \%)$.

From a 3-dimensional perspective, the horizontal axis and connectedness of the circles enable the perception of the spatial scene from above, i.e. the non-canonical support cases (in 11, 12 and 14 in both languages and 4 and 6 in Lithuanian).

Axial information is also crucial in the interpretation of containment. The central location of the Figure enables the clearest pattern of interpretation. Containment stimuli are described using a significant number of Locatives. Worth mentioning that certain taxonomy of the Locative case is observed. In central alignment (11), the Locatives denoting central of middle region appear most frequent (centre $>$ middle $>$ inner side $>$ Locative of the circle lexeme), but in NTPP and TPP oblique cases (12 and 14), first and foremost the location inside the Ground is described (using the Locative of relational nouns denoting the inner side or the Locative of circle lexeme) with only further specification referring to the exact location of the Figure.

Our study is among the first studies that experimentally test an extended set of RCC relations in respect to natural language. It is also among the first providing a comparative empirical analysis of the representations of particular spatial relations in the Baltic languages. The results show that the geometric stimuli in both languages are interpreted relatively similarly: if ambiguity of the stimulus and certain variation in responses are attested, usually they occur in both languages. However, our study has certain limitations in respect to the types of containment and support which can be explored if everyday objects (reflecting typical spatial routines) are used.

\section{Abbreviations}

1, 2, 3 - first, second, third person; ACC - Accusative; ADV - adverb; DAT - Dative; DEF definite; DEM - demonstrative; DIM - diminutive; EVD - evidential; F - femininum; FUT future; GEN - Genitive; HAB - habitual past; IDEF -indefinite; ILLAT - Illative; IMP imperative; INSTR - Instrumental; INT - interrogative pronoun; LOC - Locative; LT Lithuanian; LV - Latvian; M - masculinum; MS - manuscript; NA - non-agreement, neutral; NEG - negation; SG - singular; PA - active participle; PL - plural; PP - passive participle; PREP - preposition; PRS - present; PST - past; PTC - particle; PVB - preverb; $\mathrm{RFL}$ - reflexive.

\section{Acknowledgments}

We thank all the participants who kindly devoted their time and effort to participate in the experiment. We are grateful to Nora Bērzina for her assistance in coding the Latvian data. For Eglè Žilinskaitė-Šinkūnienè, this research is funded by the European Social Fund under the No 09.3.3-LMT-K-712 "Development of Competences of Scientists, other Researchers and Students through Practical Research Activities" measure.

\section{Data sources}

LILA - Lithuanian-Latvian-Lithuanian parallel corpus. Available at: http://tekstynas.vdu.lt/page.xhtml?id=parallelLILA.

Svens Kuzmins - Kuzmins, S. (2016). Pilsētas šamaņi. Rīga: Izdevnicība "Dienas grāmata". 


\section{References}

Ambrazas, V. (ed.) (1997). Dabartinès lietuviu kalbos gramatika, 3 pataisytas leidimas. Vilnius: Mokslo ir enciklopedijų leidybos institutas.

Ameka, F. K., Levinson, S. C. (2007). The typology and semantics of locative predicates: posturals, positionals, and other beasts. Linguistics $45,847-871$.

Asbury, A., Gehrke, B., Van Riemsdijk, H., Zwarts, J. (2008). Introduction: Syntax and semantics of spatial P. In: Asbury, A., Dotlačil, J., Gehrke, B., Nouwen, R. (Eds.), Syntax and semantics of spatial P (pp. 1-32). Amsterdam / Philadelphia: John Benjamins Publishing Company.

Auziņa, I., Breņķe, I., Grigorjevs, J., Indričāne, I., Ivulāne. B., Kalnača, A., Lauze, L., Lokmane, I., Markus, D., Nìtina, D., Smiltniece, G., Valkovska, B., Vulāne, A. (2013). Latviešu valodas gramatika. Rīga: LU Latviešu valodas institūts.

Bennett, D. C. (1975). Spatial and temporal uses of English prepositions: An essay in stratificational semantics. London: Longman.

Bowerman, M., Choi, S. (2003). Space under construction: Language-specific spatial categorization in first language acquisition. In: Gentner, D., Goldin-Meadow, S. (Eds.), Language in mind: Advances in the study of language and thought (pp. 387-427). Cambridge, MA: MIT Press.

Bowerman, M., Pederson, E. (1992). Topological relations picture series. In: Levinson, S. C. (Ed.), Space stimuli kit 1.2, 51. Nijmegen: Max Planck Institute for Psycholinguistics. Available at http://fieldmanuals.mpi.nl/volumes/1992/bowped/

Brugman, C. (1981). Story of Over. M.A. Thesis. University of California, Berkeley.

Carlson, L. A., Hill, P. L. (2003). Experimental methods for studying language and space. In: Gonzalez-Marquez, M., Mittelberg, I., Coulson, S., Spivey, M. (Eds.), Methods in cognitive linguistics. Human cognitive processing 18 (pp. 250-276). Amsterdam / Philadelphia: John Benjamins Publishing Company.

Carlson-Radvansky, L. A., Covey, E. S., Lattanzi, K. M. (1999). "What" effects on "where": Functional influences on spatial relations. Psychological science 10(6), 516-521. https://doi.org/10.1111/1467-9280.00198

Cohn, A. G., Bennett, B., Gooday, J., Gotts, N. M. (1997). Qualitative spatial representation and reasoning with the region connection calculus. GeoInformatica 1(3), 275-316.

Cooper, G. S. (1968). A semantic analysis of English locative prepositions. Cambridge, New York, Chicago, Los Angeles: Bolt Beranek and Newmann Inc.

Coventry, K. R., Carmichael, R., Garrod, S. C. (1994). Spatial prepositions, object-specific function, and task requirements. Journal of semantics 11(4), 289-309.

Coventry, K. R., Garrod, S. C. (2004). Saying, seeing and acting: The psychological semantics of spatial prepositions. Hove and New York: Psychology Press.

Davis, E., Marcus, G., Frazier-Logue, N. (2017). Commonsense reasoning about containers using radically incomplete information. Artificial intelligence 248, 46-84.

Della Penna, G., Magazzeni, D., Orefice, S. (2017). A formal framework to represent spatial knowledge. Knowledge and Information Systems 51(1), 311-338.

Dinković, I. Z., Gros, L. (2018). Spatial minds. Conceptual correlations of spatial prepositions in Hungarian, Croatian and English. Cambridge: Cambridge Scholars Publishing.

Endzelīns, J. (1971[1905]). Latyšskije predlogi. In: Endzelīns, J. Darbu izlase, Vol. 1, 307-655. Rīga: Zinātne.

Endzelīns, J. (1951). Latviešu valodas gramatika. Rīga: Latvijas valsts izdevniecība.

Feist, M. I. (2008), Space between languages. Cognitive science 32, 1177-1199. doi:10.1080/03640210802152335

Feist, M. I. (2000). On in and on: An investigation into the linguistic encoding of spatial scenes. Northwestern University, Evanston. 
Feist, M. I., Gentner, D. (2003). Factors involved in the use of in and on. In: Alterman, R., Kirsh, D. (Eds.). Proceedings of the twenty-fifth annual meeting of the cognitive science society (pp. 390-395). Hillsdale, NJ: Lawrence Erlbaum.

Feist, M. I., Gentner, D. (2012). Multiple influences on the use of English spatial prepositions: The case of "in" and "on". In: Boonthum-Denecke, C., McCarthy, P. M., Lamkin, T. (Eds.). Cross-disciplinary advances in applied natural language processing: Issues and approaches (pp. 305-323). Hershey, PA: IGI Global.

Fraenkel, E. (1929). Syntax der Litauischen Postpositionem und Präpositionen. Heidelberg: Carl Winter's Universitätsbuchhandlung.

Gärdenfors, P. (2014). The geometry of meaning: Semantics based on conceptual spaces. MIT Press.

Garrod, S., Ferrier, G., Campbell, S. (1999). In and on: investigating the functional geometry of spatial prepositions. Cognition 72(2), 167-189.

Gentner, D., Bowerman, M. (2009). Why some spatial semantic categories are harder to learn than others: The Typological Prevalence hypothesis. In: Guo, J., Lieven, E., Budwig, N., ErvinTripp, S., Nakamura, K., Özçaliskan, Ş. (Eds.), Crosslinguistic approaches to the psychology of language: Research in the tradition of Dan Isaac Slobin (pp. 465-480). New York: Psychology Press.

Sokols, E. E., Bergmane, A., Grabis, R., Lepika, M. (1959). Mūsdienu latviešu literārās valodas gramatika. Rīga: Latvijas PSR Zinātnu Akadēmijas Izdevniecība.

Hawkins, B. W. (1984). The semantics of English spatial prepositions. Doctoral dissertation. University of California, San Diego.

Herskovits, A. (1986). Language and spatial cognition. An interdisciplinary study of prepositions in English. Cambridge: Cambridge University Press.

Hespos, S. J., Spelke, E. S. (2007). Precursors to spatial language: The case of containment. In: Aurnague, M., Hickman, M., Vieu, L. (Eds.). The categorization of spatial entities in language and cognition (pp. 233-245). Amsterdam / Philadelphia: John Benjamins Publishing Company.

Holvoet, A. (1993). On the syntax and semantics of adpositional local phrases in Latvian. Linguistica Baltica 2, 131-149.

Holvoet, A. (2001). Why are prepositional phrases ousted by pure case forms in Latvian? Linguistica Baltica 9, 87-98.

Holvoet, A. (2011). Beyond external possession: Genitive and dative with locational nouns in Latvian. Baltic linguistics 2, 79-107.

Hottenroth, P.-M. (1991). Prepositions and object concepts: A contribution to cognitive semantics. Duisburg: Reproduced by L. A. U. D. (Linguistic Agency University of Duisburg).

Jamrozik, A., Gentner, D. (2015). Well-hidden Regularities: Abstract uses of in and on retain an aspect of their spatial meaning. Cognitive science 39(8), 1881-1911.

Johannes, K., Wilson, C., Landau. B. (2016). The importance of lexical verbs in the acquisition of spatial prepositions: The case of in and on. Cognition 157, 174-189.

Johnston R. J., Slobin, D. I. (1979). The development of locative expressions in English, Italian, Serbo-Croatian and Turkish. Journal of child language 6(3), 529-545.

Karulis, K. (1992). Latviešu etimologijias vārdnīca. Rīgā: Avots.

Kilius, J. (1977). Orientacinių reikšmių struktūra lietuvių kalboje (Apie vietos prielinksnių ir linksnių reikšmes). Kalbotyra 28(1), 40-49.

Kilius, J. (1980). Slankumo reikšmių struktūra lietuvių kalboje (Apie vietos prielinksnių ir linksnių reikšmes). Kalbotyra 31(1), 34-56.

Lagzdiṇa, S. (1997). Adverbi, prievārdi vai pusprievārdi? Linguistica Lettica 1, 185-205.

Lakusta, L., Landau, B. (2005). Starting at the end: The importance of goals in spatial language. Cognition 96, 1-33.

Landau, B., Johannes, K., Skordos, D., Papafragou, A. (2017). Containment and support: Core and complexity in spatial language learning. Cognitive science 41(S4), 748-779. https://doi.org/10.1111/cogs.12389 
Landau, B. (2017). Update on "What" and "Where" in spatial language: A new division of labor for spatial terms. Cognitive science 41(S2), 321-350. https://doi.org/10.1111/cogs.12410

Lemmens, Maarten (2002). The semantic network of Dutch posture verbs. In: Newman, J. (Ed.), The Linguistics of sitting, standing, and lying (pp. 103-139). Amsterdam / Philadelphia: John Benjamins Publishing Company.

Levinson, S. C. (2003). Space in language and cognition. Explorations in cognitive diversity. Cambridge: University Press.

Levinson, S. C., Wilkins, D. P. (2006). Grammars of space. Cambridge: Cambridge University Press.

Lindner, S. (1981). A lexico-semantic analysis of verb-particle constructions with up and out. Ph.D. Dissertation. University of California, San Diego.

Lindkvist, K.-G. (1950). Studies on the local sense of the prepositions in, at, on, and to, in modern English. Lund, Sweden: C. W. K. Gleerup.

Luraghi, S. (2003). On the meaning of prepositions and cases. The expression of semantic roles in Ancient Greek. Amsterdam / Philadelphia: John Benjamins Publishing Company.

Mandler, J. M. (1992). How to build a baby: II. Conceptual primitives. Psychological review 99(4), 587-604.

Mandler, J. M. (2004). The foundations of mind: Origins of conceptual thought. Oxford: Oxford University Press.

Mandler, J. M. (2010). The spatial foundations of the conceptual system. Language and cognition 2(1), 21-44.

Mani, I., Pustejovsky, J. (2012). Interpreting motion: Grounded representations for spatial language. Oxford: Oxford University Press.

Mikulskas, R. (2009). Kognityvinè lingvistika ir leksikografijos problemos. In: Judžentis, A. (Ed.), Kalba ir žmonès (pp. 39-80). Vilnius: Vilniaus universiteto leidykla.

Miller, G. A., Johnson-Laird, P. N. (1976). Language and perception. Cambridge, MA: Harvard University Press.

Navarro Ignasi i Ferrando (1998). A cognitive semantics analysis of lexical units AT, ON and IN in English. PhD Dissertation, Universitat Jaume I.

Nītiņa, D. (1978). Prievārdu sistēma latviešu rakstu valodā. Zinātne, Rīga.

Palmer, S. E., Neff, J. (1996). Late influences on perceptual grouping: Amodal completion. Psychonomic bulletin \& review 3(1), 75-80.

Przybylska, R. (2002). Polisemia przyimków polskich w świetle semantyki kognitywnej. Kraków: Universitas.

Randell, D. A., Cui, Z., Cohn, A. G. (1992). A spatial logic based on regions and connection. 3rd Int. Conf. on Knowledge Representation and Reasoning (pp. 165-176).

Rice, S. (1996). Prepositional prototypes. In: Pütz, M., Dirven, R. (Eds.), The construal of space in language and thought (pp.135-165). Berlin and New York: Mouton de Gruyter.

Rodrigues, E., Santos, P. E., Lopes, M. (2017). Pinning down polysemy: A formalisation for a Brazilian Portuguese preposition. Cognitive systems research 41, 84-92.

Rūķe, V. (1965). Dažas Raiņa valodas un stila problēmas. Ceļi XII, 3-19.

Sandra, D., Rice, S. (1995). Network analyses of prepositional meaning: Mirroring whose mind the linguist's or the language user's? Cognitive linguistics 6(1), 89-130.

Šarić, L. (2008). Spatial concepts in Slavic: A cognitive linguistic study of prepositions and cases. Wiesbaden: Harrassowitz Verlag.

Šeškauskienè, I. (2003). Proximity in English and Lithuanian. Kalbotyra 53(3), 117-125.

Šeškauskiene, I., Žilinskaitè-Šinkūnienè, E. (2015). On the polysemy of the Lithuanian $u z ̌$. A cognitive perspective. Baltic international yearbook of cognition, logic and communication: Vol. 10. https://doi.org/10.4148/1944-3676.1101

Sinha, Ch., Kuteva, T. (1995). Distributed spatial semantics. Nordic journal of linguistics 18, 167 199.

Singh, M. (2004). Modal and amodal completion generate different shapes. Psychological Science 15(7), 454-459. 
Šķilters, J., Glanzberg, M., Žilinskaitė-Šinkūnienè, E., Zariņa, L., (MS). $R C C+F$ : some applications to spatial structure in the Baltic languages.

Škilters, J., Raita, L. (2016). Functional constraints in spatial language. In: Kalnača, A., Lokmane, I., Balode, L. (Eds.), Abstracts of the international scientific conference "Baltic languages and white nights: Local meanings in language” (p. 42). Riga: University of Latvia.

Šksilters, J., Raita, L. (2015). Patterns of functional containment in Latvian. In: Kabašinskaite, B., Rinkevičius, V. (Eds.), 12th international congress of balticists, Vilnius University, Lithuania, October 28-31 (p. 168). Available at: http://www.baltistukongresas.flf.vu.lt/failai/tezes/Skilters_Raita.pdf.

Stasiūnaite, I., Šeškauskiene, I. (2004). On the meaning of on/ant: how relevant is the concept of contact? Kalbotyra 54(3), 69-75.

Stefanowitsch, A., Rohde, A. (2004). The goal bias in the encoding of motion events. In: Radden, G., Panther, K.-U. (Eds.), Studies in linguistic motivation (pp. 249-267). Berlin and New York: Mouton de Gruyter.

Šukys, Jonas (1998). Lietuviu kalbos linksniai ir prielinksniai: vartosena ir normos. Kaunas: Šviesa.

Svorou, S. (1994). The grammar of space. Amsterdam / Philadelphia: John Benjamins Publishing Company.

Svorou, S. (2007). Relational constructions in cognitive linguistics. In: Geeraerts, D., Cuyckens, H. (Eds.), The Oxford handbook of cognitive linguistics (pp. 726-752). Oxford: Oxford University Press.

Talmy, L. (1972). Semantic structures in English and Atsugewi. University of California at Berkeley.

Talmy, L. (1985). Lexicalization patterns: semantic structure in lexical forms. In: Shopen, T. (Ed.), Language typology and syntactic description 3: Grammatical categories and the lexicon (pp. 57-149). Cambridge: Cambridge University Press.

Talmy, L. (2000a). Toward a cognitive semantics. Volume I: Concept structuring systems. Cambridge, MA: MIT Press.

Talmy, L. (2000b). Toward a cognitive semantics. Volume II: Typology and process in concept structuring. Cambridge: MIT Press.

Ulvydas, K., Ambrazas, V., Valeckienè, A. (Eds.) (1976). Lietuvių kalbos gramatika 3: Sintaksè. Vilnius: Mokslas.

Valiulytè, E. (1998). Dabartinès lietuviu kalbos sintaksiniai sinonimai. Vietos, laiko ir priežasties raiška. Vilnius: Mokslo ir enciklopedijų leidybos institutas.

Vandeloise, C. (1991). Spatial prepositions. A case study from French. Chicago and London: The University of Chicago Press.

Vandeloise, C. (1994). Methodology and analyses of preposition in. Cognitive Linguistics 5(2), 157-184.

Vasardani, M., Stirling, L. F., Winter, S. (2017). The preposition at from a spatial language, cognition, and information systems perspective. Semantics and pragmatics 10, Article 3 , https://doi.org/10.3765/sp.10.3.

Wälchli, B. (2001a). A typology of displacement (with special reference to Latvian). Sprachtypologie und Universalienforschung 45(3), 298-323.

Wälchli, B. (2001b). Lexical evidence for the parallel development of the Latvian and Livonian verb particles. In: Dahl, Ö., Koptjevskaja-Tamm, M. (Eds.), The Circum-Baltic languages. Volume 2: Grammar and typology (pp. 413-441). Amsterdam / Philadelphia: John Benjamins Publishing Company.

Wiemer, В. (2013) = Вимер, Б. (2013). Значимость способов модификации глагольных основ для оценки ареальной дифференциации балтийских языков (по сравнению с рядом славянских микроязыков). In: Ivanov, Vjač. Vs., Arkad'ev, P. M. (Eds.), Tipologija slavjanskich, baltijskich i balkanskich jazykov (v svete jazykovych kontaktov) [Studies in the typology of Slavic, Baltic and Balkan languages (with primary reference to language contact)] (pp. 220-246). Saint-Petersburg: Aletheia. 
Wunderlich, D. (1991). How do prepositional phrases fit into compositional syntax and semantics? Linguistics 29, 591-621.

Wunderlich, D., Herweg, M. (1991). Lokale und Direktionale. In: Von Stechow, A., Wunderlich, D. (Eds.), Semantik: Ein internationales Handbuch der zeitgenössischen Forschung (pp. 758-785). Berlin and New York: Walter De Gruyter.

Zaika, N. (2016). The directive/locative alternation in Lithuanian and elsewhere. In: Holvoet, A., Nau, N. (Eds.), Argument realization in Baltic (pp. 333-360). Amsterdam / Philadelphia: John Benjamins Publishing Company.

Žilinskaitè-Šinkūnienè, E., Šķilters, J., Glanzberg, M. [MS]. Spatial relations in the Baltic languages.

Zwarts, J. (2017). Spatial semantics: Modeling the meaning of prepositions. Language and linguistics compass 11(5). https://doi.org/10.1111/lnc3.12241

Received February 26, 2019, revised April 23, 2019, accepted April 29, 2019 